
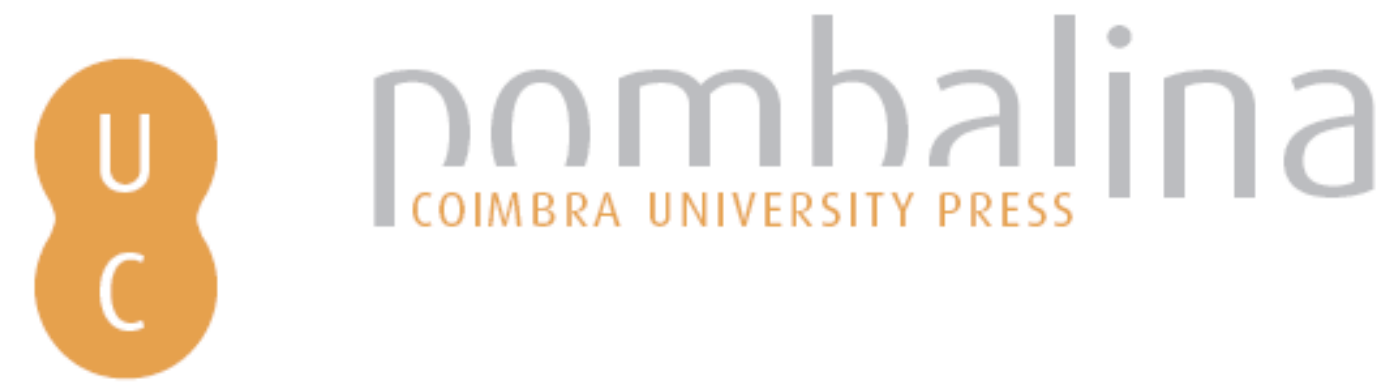

\title{
Um percurso temático no tempo: as vidas paralelas de Plutarco e a pintura europeia do século XVI ao século XIX: primeiras abordagens
}

\begin{tabular}{ll} 
Autor(es): & Rodrigues, Paulo Simões \\
Publicado por: & $\begin{array}{l}\text { Centro de Estudos Clássicos e Humanísticos; Imprensa da Universidade } \\
\text { de Coimbra }\end{array}$ \\
$\begin{array}{l}\text { URL } \\
\text { persistente: }\end{array}$ & URI:http://hdl.handle.net/10316.2/31536 \\
DOI: & DOI:http://dx.doi.org/10.14195/978-989-8281-57-9_2 \\
Accessed : & 26-Apr-2023 14:11:22 \\
\hline
\end{tabular}

A navegação consulta e descarregamento dos títulos inseridos nas Bibliotecas Digitais UC Digitalis, UC Pombalina e UC Impactum, pressupõem a aceitação plena e sem reservas dos Termos e Condições de Uso destas Bibliotecas Digitais, disponíveis em https://digitalis.uc.pt/pt-pt/termos.

Conforme exposto nos referidos Termos e Condições de Uso, o descarregamento de títulos de acesso restrito requer uma licença válida de autorização devendo o utilizador aceder ao(s) documento(s) a partir de um endereço de IP da instituição detentora da supramencionada licença.

Ao utilizador é apenas permitido o descarregamento para uso pessoal, pelo que o emprego do(s) título(s) descarregado(s) para outro fim, designadamente comercial, carece de autorização do respetivo autor ou editor da obra.

Na medida em que todas as obras da UC Digitalis se encontram protegidas pelo Código do Direito de Autor e Direitos Conexos e demais legislação aplicável, toda a cópia, parcial ou total, deste documento, nos casos em que é legalmente admitida, deverá conter ou fazer-se acompanhar por este aviso.

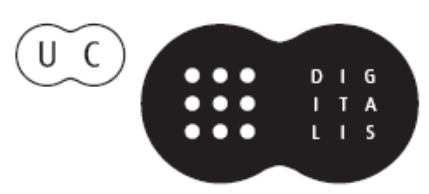


Colecção Autores Gregos e Latinos SÉRIE ENSAIOS

\section{Luísa de Nazaré Ferreira \\ Paulo Simôes Rodrigues Nuno Simões Rodrigues}

\section{Plutarco e as Artes}

Pintura, Cinema e Artes Decorativas

IMPRENSA DA UNIVERSIDADE DE COIMBRA COIMBRA UNIVERSITY PRESS 


\section{UM PERCURSO TEMÁTICO NO TEMPO: \\ As Vidas Paralelas de Plutarco e a pintura \\ EUROPEIA DO SÉCULO XVI AO SÉCULO XIX. \\ Primeiras Abordagens}

Paulo Simões Rodrigues

(Universidade de Évora)

O objecto do presente estudo é proceder a uma primeira abordagem da análise das Vidas Paralelas de Plutarco enquanto fonte e tema da pintura de história, numa baliza cronológica de longa duração que vai do século XV ao século XVIII. Salientamos o critério pré-definido da longa duração porque radica nele a natureza introdutória da análise que aqui nos propomos fazer. Introdutório porque nos interessa entender de que modo as figuras retratadas nas Vidas Paralelas de Plutarco e os episódios com elas relacionados aí narrados se constituíram, enquanto tema de pintura, na representação de uma ideia de história que, independentemente das contingências circunstanciais que envolveram a produção de cada obra que tomou Plutarco como referência temática ou do sentido concreto que cada autor conferiu à personagem ou ao episódio seleccionado, parece ser estruturante de um conceito de temporalidade evolutiva, cumulativa e civilizadora, iniciada no Renascimento e que ainda perdura.

No início do Renascimento, a partir de finais do século XIV, o conceito teológico de tempo predominante na Idade Média, subordinado a uma 
noção transiente da vida terrena, passou a coexistir com uma consciência do tempo enquanto dimensão da acção, da descoberta e da transformação. Nesta nova consciência do tempo, consolida-se a convicção de que o passado estruturou o presente, assim como o presente deverá estruturar o futuro, que se virá a tornar num novo presente, numa linha contínua, irreversível e progressiva em que a experiência humana se vai acumulando, fazendo da modernidade o «anão que está em cima dos ombros de um gigante e por isso é capaz de ver mais longe» ${ }^{1}$, em conformidade com a máxima atribuída a Bernard de Chartres (séc. XII). Mesmo quando essa construção de futuro foi baseada numa pretensa Idade de Ouro passada, nunca esteve em causa um regresso a esse momento primordial, mas a recuperação e a actualização de um modelo de cultura, de moral e de sociedade. Daí considerarmos que esta apropriação do passado como referência estruturante do futuro não implica necessariamente uma perspectiva circular da história, podendo ser cíclica ou em «espiral simbolicamente ascendente» ${ }^{2}$. A divisão da história ocidental nas três eras da Antiguidade, Idade Média e Modernidade, que data dos primórdios do Renascimento, implica esta perspectiva cíclica do tempo.

No que diz respeito à pintura de temática plutarquiana, em concreto à alusiva às Vidas Paralelas, interessa-nos partir da continuidade e da frequência

\footnotetext{
${ }^{1}$ Calinescu (1999) 27.

${ }^{2}$ Calinescu (1999) 25-38.
} 
com que a ela se recorreu no tempo longo, do século XVI ao século XIX, para compreender em que medida foi, mais que a mera ilustração de uma narrativa, um instrumento de consciencialização da realidade em construção que é o presente e o futuro próximo. Mas também de legitimação, pela apresentação de exemplos de personagens e acontecimentos do passado, das opções tomadas na consubstanciação desse presente e na preparação desse futuro. Em suma, a pintura de história enquanto representação visual de uma relação com o tempo e designadamente a pintura de temática plutarquiana enquanto imagem do sentido de uma determinada interpretação da História.

Ao revelar uma perspectiva do tempo e uma ideia da História numa imagem, o pintor está a atribuir-lhes uma dimensão sensorial que as transforma numa experiência para o espectador, ou seja numa realidade mais concreta que a abstracta narrativa dos acontecimentos e até que a materialidade dos vestígios arqueológicos e dos monumentos históricos, na medida em que é a acção dos eventos e a figuração das personagens a que a informação histórica se refere que estão ali perante o observador. $\mathrm{O}$ elevado grau de verosimilhança e dramaticidade que muitas destas pinturas atingiram levam, quando exibidas, a que o espectador se identifique com as cenas representadas, o que as consagra, dentro da dialéctica emotiva, estética e retórica que estabelece com quem as observa, como verdade histórica. Neste sentido, curioso o paralelismo que podemos estabelecer com 
a biografia enquanto género histórico, na medida em que a organização da cadeia de acontecimentos a que alude não está subordinada às relações de causa e efeito, mas à caracterização do biografado e ao seu papel no desenrolar dos factos. Ao centrar a perspectiva de relação com o tempo no ponto de vista de um indivíduo, daquele sobre quem se escreve ${ }^{3}$, a biografia faz com que a compreensão do significado histórico dos eventos protagonizados pelo biografado seja determinada pela intensidade da identificação que o leitor estabeleça com essa personagem cuja vida está a ser narrada. Deste modo, existe sempre a poderosa possibilidade da verdade histórica ser a verdade do biógrafo, tanto como na pintura de história pode ser a do pintor. Biografia e pintura de história são espécies ambíguas, a metade do caminho entre a história e a ficção novelesca ou a representação artística ${ }^{4}$. Afirmam uma finalidade política, moral ou religiosa que ganha estilização e tipificação na personalidade ou no facto a ela ligada, e vêm ao encontro da curiosidade do público pelas figuras heróicas, representativas e exemplares, e à sua necessidade de se identificarem com personagens consideradas superiores. De ressalvar, contudo, que enquanto o registo literário da biografia permite fazer o inventário dos acontecimentos protagonizados pelo biografado dentro do processo histórico, a pintura tem de seleccionar e concentrar a atenção do espectador num acontecimento ou numa acção.

${ }^{3}$ Rodrigues (2002) 127-128.

${ }^{4}$ Bauzá (2002) 183. 
No seu tratado Da Pintura (1435) $)^{5}$ o arquitecto renascentista Leon Battista Alberti afirma que o objecto da pintura é a historia, considerando-a, a bistoria, o maior feito do pintor ${ }^{6}$. De acordo com a historiografia, historia ou istoria foi um termo usado pela primeira vez, no contexto da produção pictórica, no século XV. A sua aplicação veio designar os novos e complexos temas narrativos que por essa altura começaram a enriquecer o reportório dos pintores ${ }^{7}$. Ao concentrar a pintura no conceito de historia, Alberti parece entender a pintura como uma narrativa visual, com muitas figuras, de temáticas que iam da religião aos acontecimentos recentes. Alberti atribui esta relevância narrativa à pintura para estabelecer uma analogia com a retórica clássica, à maneira de Cícero e Quintiliano, de modo a elevar a pintura ao estatuto de actividade intelectual, ou de arte liberal, e, por consequência, fazer ascender o lugar do pintor na sociedade, que assim deixava de ser um mero artista manual, embora o fosse de nível superior. À semelhança da poesia, a pintura devia interpretar e representar as emoções humanas organizando as figuras e os elementos nos diferentes planos da composição pictórica como palavras numa frase poética. Daí a necessidade do artista conceber a pintura na sua imaginação antes de a executar, o que

${ }^{5}$ Escrito originalmente em latim, provavelmente entre 1438 e 1444, foi dedicado a Giovanfrancesco Gonzaga de Mântua. Traduzido para italiano corrente, para o arquitecto florentino Filippo Brunelleschi, por volta de Julho de 1436. Grayson (1972) 3.

${ }^{6}$ Alberti, Da Pintura I, 33 e 60.

${ }^{7}$ Emison (1996) 613-615. 
significa que a pintura era, em primeiro lugar, ideia, o que fazia dela uma actividade mental.

A fim de demonstrar a superioridade intelectual da arte da pintura, muitos teóricos renascentistas, entre os quais está Leonardo da Vinci, defenderam que os pintores deviam pintar apenas seres superiores, deuses e heróis. Deriva desta convicção a frequente associação do termo historia aos temas da Antiguidade clássica, retirados das fontes literárias, considerados os mais exaltantes e exigentes, aqueles que melhor conduziam à edificação do público. Esta atitude, no entanto, também fomentou a generalização das personagens tipificadas, em detrimento da composição de personagens específicas, situação que nos conduz à problematização da acepção do conceito albertiano de historia, tal como foi compreendido pela cultura artística renascentista e pelas suas derivações, e pela própria historiografia. Designadamente a correspondência estabelecida da historia com o tema ou discurso narrativo da pintura, que consideramos redutora em relação à explicitação do termo empreendida pelo próprio Alberti no Da Pintura.

Segundo Alberti, uma historia que se pode verdadeiramente admirar é aquela que se mostre por si mesma tão atractiva e adornada que prenda os olhos do espectador, do instruído e do não instruído, durante muito tempo, com prazer e emoção. $\mathrm{O}$ primeiro aspecto a criar prazer numa historia é a abundância e a variedade dos elementos figurados na pintura. Uma historia abundante é aquela que dá a ver, nos seus lugares apropriados, envolvidos, de modo adequado 
ao que se quer dar a ver, velhos, homens, adolescentes, crianças, matronas, raparigas, recém-nascidos, animais domésticos, cães, aves, cavalos, cordeiros, edifícios, territórios, etc ${ }^{8}$.

Alberti aprofunda o conceito especificando que a historia comove os ânimos dos espectadores quando as emoções das personagens representadas são expressas com clareza e verosimilhança, permitindo que observador se identifique com o que está a observar e, nas palavras do próprio arquitecto italiano, chore com os que choram, ria com os que riem, sofra com os que sofram. Essa clareza e verosimilhança das emoções deve manifestar-se nos movimentos do corpo. Assim, os tristes, perturbados pelas preocupações e obcecados pela aflição, revelam-se entorpecidos em todos os seus sentidos e forças, pálidos, lânguidos e com os membros vacilantes; os que se lamentam apresentam-se com a face congestionada, o pescoço lânguido, fatigados e descuidados; os zangados, cujas paixões estão acesas pela ira, mostram-se com o rosto e os olhos marcados pela cólera, e com movimentos violentos e agitados, em conformidade com o furor da sua irascibilidade; nos alegres e joviais, os movimentos são soltos e agradáveis 9 .

A exposição que Alberti faz do significado que atribui ao termo historia demonstra que este é mais que o tema da pintura, é a acção, o que vai ao encontro do defendido pela poética aristotélica, de que a acção

${ }^{8}$ Alberti, Da Pintura I, 40.

${ }^{9}$ Alberti, Da Pintura I, 40-41. 
humana é o objecto de pintores e poetas ${ }^{10}$. Mas a acção entendida como o processo dinâmico de transmissão do tema que representado pela pintura inclui a maneira como é composto formalmente e configurado, ou seja como se materializa pela intermediação da figuração. Esta noção era particularmente relevante porque, no que concerne à pintura renascentista, ao contrário do que sucedia para a Arquitectura e a Escultura, não existiam modelos temáticos e formais antigos, quer na tratadística - como os Dez Livros de Arquitectura de Vitrúvio - quer na Arqueologia - como as ruínas e as esculturas que podiam ser admiradas e copiadas pelos artistas. Desta situação decorreu o predomínio dos modelos da arquitectura e da escultura na cultura artística moderna, a importância do desenho no esquema compositivo da pintura e a concentração do debate teórico nas problemáticas da representação dos objectos no espaço e da verosimilhança em relação à natureza ${ }^{11}$. O português Francisco de Holanda demonstra-o em 1548, quando descreve o que devia ser a composição da acção numa obra pictórica alusiva à conquista da cidade de Tróia pelos Gregos:

E assim mesmo mostra mui presente e vesivelmente todo aquelle incendio d'aquella cidade, em todas as suas partes, representado e visto tấo igualmente como se fosse mui vero: d'uma banda os que fogem polas ruas e praças: da outra os que laçam dos muros e torres; d'outra parte os templos meio derribados e o resplendor da flama sobre

${ }^{10}$ Aristóteles, Poética 1448a1-5.

${ }^{11}$ Villa (1999) 27. 
os rios; as praias sigeas alumiadas; Pantho como foge com os idolos manquejando, trazendo pola mão seu neto; o cavallo troiano como pare os armados no meo de uma gram praça... [...] Parece-vos que cheiraes o fumo, que fugis da flama, que temeis as ruinas dos edificios; estaes para dar a mão aos que caem, staes para defender aos que pelejam com muitos; para fugir com os que fogem, e para star firme com os esforçados ${ }^{12}$.

No texto, está muito presente a noção da história vivenciada, que apela à emoção e ao sentimento (pathos), o que na pintura é relevante, pois os modelos clássicos seguidos, de origem literária, eram algo mais teórico e emotivo do que concreto e objectual.

O entendimento da pintura enquanto acção é fundamental para compreendermos a relevância que a pintura de história - aqui no sentido de conjunto de conhecimentos relativos ao passado - vai ganhar nos séculos seguintes. Ainda tomando Alberti como referência, salientamos a sua afirmação de que a pintura tem em si uma força tão divina que não só torna presentes os ausentes, como apresenta aqueles que morreram há séculos com a aparência de vivos e de um modo que faz com que sejam reconhecidos pelos espectadores com prazer e suma admiração pelo artista. Alberti recorre precisamente ao exemplo de Plutarco, às biografias que o autor grego escreveu de Alexandre da Macedónia e de Agesilau para demonstrar como a arte, e em particular a pintura, pode preservar os rostos dos defuntos durante muito

${ }^{12}$ Holanda (1984a) 271-272. 
tempo, concedendo-lhes uma espécie de imortalidade que aproxima os mortais dos deuses ${ }^{13}$. Plutarco conta como um dos comandantes de Alexandre, Cassandro, tremeu ao reconhecer a majestade do seu rei defunto num retrato ${ }^{14}$ e que o lacedemónio Agesilau nunca quis ser pintado ou esculpido por estar consciente de uma sua deformidade física, recusando que o conhecimento da sua efígie passasse à posteridade ${ }^{15}$.

Cerca de 63 anos depois de Alberti, por volta de 1498, o pintor Leonardo da Vinci escrevia que se o poeta narrava uma história com a pintura da sua pena, o pintor fazia-o com o seu pincel, mais deleitosa e menos árdua de entender ${ }^{16}$. Na centúria seguinte, Francisco de Holanda referia que a pintura mostrava presentes os «varões que há tanto tempo que passaram, e de que já não aparecem nem os ossos sobre a terra para os podermos imitar em seus feitos claros? Nem de como nos mostra seus conselhos e batalhas, por exemplos e histórias deleitosas, seus actos fortes, sua piedade e costumes?». Dava a ver «os trajos peregrinos ou antigos, a variedade das gentes e nações estranhas, dos edifícios, das alimárias e monstros, que em escritos seriam prolixos de ouvir, e enfim mal entendidos». A pintura punha diante dos olhos «a imagem de qualquer grande homem, por seus feitos desejado de ser visto e conhecido...» ${ }^{17}$.

Até ao final da primeira metade da centúria de

13 Alberti II, 25.

${ }^{14}$ Plutarco, Alexandre 74.4-6.

${ }^{15}$ Plutarco, Agesilau 2.2-4.

${ }^{16}$ Vinci 23, Urb. 8a, 9 a.

${ }^{17}$ Holanda (1984b) 34. Citação do Primeiro Diálogo. 
XIX, a pintura de história esteve ao serviço de uma afirmação de historicidade por parte de elites que quiseram asseverar a sua própria responsabilidade histórica, embora com finalidades distintas, ao sabor das circunstâncias de cada época. De finais do século XIV ao século XVI, durante todo o Renascimento clássico, a pintura de história foi influenciada pela concepção dominante de Antiguidade: um mundo heróico ideal, habitado por heróis convertidos em exemplos a imitar, patente, por exemplo, em De Viris Illustrium de Petrarca. Este era um tema particularmente pertinente na Península Itálica, onde os poderes políticos se consideravam herdeiros dos imperadores romanos e proliferavam as cidades autónomas, como Florença ou as repúblicas de Veneza e Génova, cuja independência era frequentemente ameaçada por potências superiores, como o Papado ou o Império Sacro-Romano. Compreende-se assim as referências que a arte italiana faz ao passado e aos heróis da Antiguidade, passíveis de serem tomados como exemplos da dedicação à pátria ou à cidade, tão necessária no presente ${ }^{18}$.

$\mathrm{Na}$ primeira metade do século XVI, passa a vigorar uma noção mais conceptual da História, de cariz platónico. Deste modo, a arte do Maneirismo concebe a história como alegoria dos factos e a alegoria como o momento culminante da História, representando-a de uma forma mais dinâmica, de imediata compreensão e efeito sobre o espectador, de

${ }^{18}$ Nieto Alcaide, Checa (1994) 33-44 e 244-250. 
exaltação heróica de quem encomendou a obra ou da temática nela abordada ${ }^{19}$.

No período barroco, sob a influência do ascendente que a poética aristotélica foi adquirindo desde a segunda metade do século XVI, a História passa a ser representada com um sentido de maior verosimilhança e moral. O conceito abstracto da ideia de história chega a ganhar uma aparência naturalista. A História é testemunha da memória e da verdade, devendo ser apresentada na pintura de uma maneira directa, simples e verosímil, alicerçada na realidade Fréart de Cambray defendia que as composições de carácter histórico deviam obedecer do modo mais rigoroso à verdade estrita. A expectativa em relação ao cumprimento destes preceitos era tão impositiva que alguns pintores viram-se obrigados a esclarecer a fronteira que separava a criação artística com base no conhecimento histórico da história. O pintor francês Nicolas Poussin respondeu às críticas feitas a determinadas inexactidões históricas detectadas em algumas das suas obras esclarecendo que o artista era livre de representar as coisas como foram no passado e como eram no presente, ou como deviam ter sido nesses dois momentos. Um outro pintor francês, Charles Le Brun, ao comentar uma pintura de Poussin numa sessão da Academia, justificava as liberdades artísticas distinguindo os modos de expressão do historiador e do pintor. Enquanto o primeiro podia, ao longo do seu discurso, apresentar sucessivamente os diferentes

${ }^{19}$ Nieto Alcaide, Checa (1994) 305-316. 
acontecimentos, o segundo tinha que fazer o mesmo num único instante, o do quadro, representando em simultâneo acontecimentos que se haviam desenrolado de modo sucessivo ${ }^{20}$.

Ainda sob os cânones da estética barroca, o século XVII assistiu à autonomização da pintura de história enquanto género pictórico e à sua consagração pela Academia que a elevou à mais alta categoria na ordem dos temas que o pintor podia escolher para trabalhar. A Academia, cuja função institucional era garantir o estatuto social dos pintores, de modo a que não voltassem a ser considerados simples artífices especializados, estabeleceu uma rígida hierarquia dos géneros que era liderada pela pintura de história, seguida pelo retrato, pela pintura de género, pela paisagem e pela natureza-morta ${ }^{21}$. A pintura de história era o mais elevado dos géneros e o mais alto feito a que um pintor podia aspirar porque obrigava a uma profunda modificação da realidade observável. Ao autor de pintura de história não bastava pintar a sua perspectiva das personagens e dos factos, tinha que saber retratar a figura humana de forma convincente e compor as paisagens ou os interiores, incluindo os pormenores dos objectos e dos elementos naturais, que deviam enquadrar as figuras nos cenários adequados

${ }^{20}$ Checa, Morán (1989) 119 e 120.

${ }^{21}$ No século XVII, o conceito de pintura de História abrangia a história profana e religiosa, as narrativas literárias, mitológicas e alegóricas, e os estudos individuais de personagens santas como a Virgem Maria. Pintura de género era a designação atribuída às cenas do quotidiano e que se vulgariza no século XVIII. Walsh (1999) 93. 
à sua condição histórica. As reacções emocionais das personagens tinham de parecer autênticas e corresponder à narração dos acontecimentos a que estavam ligadas.

A aplicação dos preceitos académicos não estava, porém, isenta de debate. Ainda no século XVII, no seio da Academia de São Lucas de Roma, entre os seus membros espoletou uma polémica sobre se os temas históricos deviam ser representados com poucas ou muitas figuras. Classicistas como Sacchi e Nicolas Poussin tendiam para as composições limitadas, nas quais se podia valorizar com clareza cada gesto e cada movimento. Estavam convictos que a mensagem histórica devia ser transmitida por meio da expressão das personagens, devendo estas estar, com essa finalidade, perfeitamente individualizadas e circunscritas no espaço da pintura. Um quadro devia ser lido como um poema ou uma tragédia, em que cada personagem tinha a sua função claramente definida. Igualmente através da comparação da pintura com a poesia - embora não com a tragédia mas com a épica-, alguns pintores, como Pietro de Cortona, sustentaram a antítese, segundo a qual, paralelamente à acção principal, se desenrola toda uma série de episódios secundários, de modo a que a multiplicação de grupos e cenas não dificulte a leitura do conjunto, mas antes enriqueça a composição ${ }^{22}$.

Regulamentada por uma certa ortodoxia estética e iconográfica, necessária à sua eficácia e implícita em certos preceitos do belo e da sua representação,

${ }^{22}$ Checa, Móran (1989) 120 e 121. 
nomeadamente nas obras mais académicas, a pintura de história entra numa fase de estagnação criativa durante a primeira metade do século XVIII, que acarreta a desvalorização do género, até no seio da própria Academia. Em 1727, em França, chega-se a organizar um concurso para estimular a produção de pintura de história. A situação muda a partir de 1760. Estimulada pelos livros de Johann Joachim Winckelmann sobre arte grega e pelo surto das descobertas arqueológicas de Pompeios e Herculano, difundidas por toda a Europa através da gravura, a Antiguidade Clássica recebeu uma renovada atenção. Com a Revolução Francesa (1789), a Antiguidade ganha um novo valor ideológico, tornando-se símbolo apologético dos valores da República e depois, com Napoleão Bonaparte, do Império francês. Os nacionalismos oitocentistas fomentaram ainda mais a pintura de história, mas agora sobretudo ligada aos episódios e às personagens do passado da própria nação, seja relativos ao mais antigo - sobretudo a Idade Média -, seja ao mais recente.

Os limites cronológicos dentro dos quais analisámos o desenvolvimento da pintura de história correspondem, genericamente, às datações que balizam o conjunto de obras de temática plutarquiana que conseguimos recolher, em número de 174 composições, entre iluminuras, pinturas murais e 
telas $^{23}$, que certamente não são a totalidade de pinturas que recorreram às Vidas Paralelas como fonte temática, mas são um universo suficientemente representativo para encetar as primeiras problematizações da relação $\mathrm{da}$ arte com o tempo, numa perspectiva temporal.

Efectivamente, as obras mais antigas que identificámos terão sido realizadas por volta de 1410, estão atribuídas a um Mestre de Luçon e são duas iluminuras que aludem a dois episódios retirados da vida de António, um Banquete de Cleópatra ${ }^{24}$ e a Morte de António e Cleópatra ${ }^{25}$. As duas iluminuras fazem parte da tradução francesa de uma obra de Boccaccio, Des cas des nobles hommes et femmes (De casibus uirorum ilustrium), e aparecem no segundo volume, a primeira no fólio 26 e a segunda no fólio 66. A obra inscreve-se num género literário muito em voga no século $X V$, de intenções panegíricas e moralizantes, sem argumento narrativo, seguindo somente a ordem cronológica da vida das personagens retratadas, em conformidade com o modelo biográfico das Vidas Paralelas de Plutarco. Corresponde à visão quatrocentista da Antiguidade enunciada páginas atrás, a de um mundo habitado por heróis exemplares. Em termos formais, salientamos a Morte de António e Cleópatra, síntese visual de dois

${ }^{23}$ Não considerámos sequer outro tipo de registos artísticos além da pintura (mesmo no âmbito das Artes Visuais, como o desenho e a gravura), pois essa tarefa revelar-se-ia verdadeiramente hercúlea, diriamos mesmo impossível de desenvolver individualmente, só ao alcance de uma equipa de investigação, em prazos bem mais alargados.
${ }^{24}$ Plutarco, António 28.
${ }^{25}$ Plutarco, António 74; 76-78; 84-86. 
momentos narrativos autónomos, que a iluminura junta na mesma representação, prática comum na pintura medieval, a de fazer coincidir tempos distintos num único espaço, com a finalidade de tornar a mensagem visual, neste caso o teor moralizante, mais eficaz. Em termos dos sistemas de narratividade na representação artística, é uma solução muito próxima da narrativa de «momento», a qual revela a essência dos dois episódios ${ }^{26}$. Aqui, ao associar dois momentos diferentes, o iluminador revela a causa comum das duas mortes, a ambição política partilhada por António e Cleópatra, e o seu desfecho trágico provocado pela derrota militar infligida por Octávio Augusto.

Quanto à obra mais recente, data de 1899 , intitula-se Vercingétorix rende-se a César e é da autoria de Lionel-Nöel Royer. Esta alude ao episódio da rendição de Vercingétorix, chefe dos Gauleses, descrito por Plutarco na vida de Júlio César. Plutarco conta como Vercingétorix, depois de pegar nas suas armas mais belas e arrear ricamente o seu cavalo, montou-o, deu uma volta em redor de Júlio César, que estava sentado, apeou-se, atirou a sua armadura ao chão e sentou-se aos pés do general romano, mantendo-se imóvel até que o levaram acorrentado para o desfile triunfa ${ }^{27}$. A pintura de Royer detém-se no momento em que Vercingétorix atira a armadura ao chão perante um Júlio César sentado, rodeado pelo seu exército. É bastante fiel ao passo de Plutarco,

${ }^{26}$ Lopes (2003) 45-46.

${ }^{27}$ Plutarco, César 27. 
acrescentado-lhe unicamente a expressão das emoções dos protagonistas, assim como a recriação do ambiente de um campo militar, elementos necessários ao cânone da verosimilhança da pintura de história. Tematicamente, pertence à categoria das pinturas de carácter nacionalista de finais do século XIX, neste caso em contexto francês, mas em que o herói pátrio não se destaca pela vitória na guerra, mas pela dignidade na derrota, perante um inimigo mais numeroso e poderoso.

O período em que se regista a maior produção de pintura de temática histórica baseada nas Vidas Paralelas de Plutarco estende-se do século XVII ao século XVIII (62\% das obras levantadas), com particular incidência no século XVII $(32,2 \%)^{28}$. A verificação destes dados vem ao encontro do que atrás escrevemos sobre a pintura de história, nomeadamente o ter-se consagrado no século XVII enquanto género autónomo e ter sido considerada, ainda nessa centúria, pela Academia, a mais elevada das categorias temáticas da pintura.

No que respeita aos conteúdos temáticos, ou sejà̀ selecção das personagens ou das situações a representar, numa abordagem diacrónica, é de sublinhar em primeiro lugar que os pintores se concentraram numa pequena parcela dos 50 biografados por Plutarco nos livros que constituem o conjunto das Vidas Paralelas. Para além disso, a presença dos latinos é nitidamente superior aos gregos, que muito deverá ao ascendente

${ }^{28}$ Estas percentagens dizem respeito às obras inventariadas no decurso desta investigação, não significando por isso necessariamente valores exaustivos. 
do Império Romano enquanto referente histórico modelar das ideias de República, Império, governo e civilização, desde o Renascimento ao Romantismo.

As representações mais frequentes são, por ordem crescente, as de Rómulo e Remo, Coriolano, Júlio César, Catão, Alexandre e Cleópatra, por vezes associada a duas outras figuras, Marco António e Octávio Augusto. A Cleópatra, caso interessante porque não foi ela a directamente biografada por Plutarco, surgindo pelo papel fulcral que teve nas vidas de Júlio César e Marco António, que na pintura surgem como figuras complementares à da rainha egípcia, regressaremos mais adiante. Por agora, abordaremos as restantes.

Rómulo e Remo, mito fundador de Roma interpretado como realidade factológica, podem estar presentes por evocação, em cenas que fazem parte da sua história, mas em que eles não aparecem, como sucede com os seus progenitores em Marte e Reia Silvia (1616-1617) de Pieter Paulo Rubens ${ }^{29}$. Também pela situação, ou seja na representação de uma situação em que estiveram directamente envolvidos, embora não figurem como protagonistas da composição, sendo mesmo por vezes de difícil identificação. É o que sucede nas diferentes variações do Rapto das Sabinas e da Intervenção das Mulheres Sabinas ${ }^{30}$. Finalmente, os episódios retirados directamente das suas biografias, nomeadamente o momento em que o pastor Fáustulo

\footnotetext{
${ }^{29}$ Cf. Plutarco, Rómulo 1-4.

${ }^{30}$ Cf. Plutarco, Rómulo 14-19.
} 
os encontrou, depois da morte de sua mãe e do seu abandono, para que também morressem ${ }^{31}$. Ou então cenas que tentam figurar fases da vida dos biografados apenas enunciadas pelas fontes e não descritas, mas às quais a pintura deu uma dimensão visual, tornando-a experiência, logo facto. Assim acontece com a infância de Rómulo e Remo em casa de Fáustulo e de sua mulher Aca Larência ${ }^{32}$.

Abordaremos as figuras de Júlio César e Catão em conjunto. Não apenas porque estão ligados historicamente, pelo seu protagonismo nos acontecimentos que levaram ao fim da República romana, no século I a.C., mas também pela analogia do simbolismo que personificaram na arte. Ambos protagonizam uma morte violenta, Catão suicida-se em 46 a.C..$^{33}$, depois de confrontado com a falência da sua luta pela velha ordem republicana, César é assassinado no Senado nos Idos de Março de 44 a.C. por, ao ter introduzido um poder personalizado e autocrático, ser visto como uma ameaça à República ${ }^{34}$. Ambos simbolizam o sacrifício pessoal em nome de ideais políticos, especialmente dos ideais republicanos, o que explica a frequência dos temas das mortes de Catão e de Júlio César no período pós-revolução francesa - vejam-se as obras de Louis-André-Gabriel

${ }^{31}$ Cf. Plutarco, Rómulo 6.

32 Plutarco, Rómulo 4.4-5.

33 Plutarco, Catão-Menor 64-73. A descrição que Plutarco faz do suicídio de Catão é particularmente pormenorizada, dramática e pitoresca. Geiger (1996) 80.

${ }^{34}$ Plutarco, César 62-67. 
Bouchet (1797), Pierre Bouillon (1797) e Vincenzo Camuccini (c. 1800).

Mas, Júlio César é também representado como herói militar - O Triunfo de César (c. 1800) de Vincenzo Camuccinni -, modelo triunfante para líderes políticos e militares desde a Idade Média à Contemporaneidade. É igualmente o estatuto de herói militar que explica a popularidade de Alexandre da Macedónia, por isso Plutarco põe-no em paralelo com Júlio César, e de Coriolano, aceite como figura real, entre os pintores de História. Em particular, um passo específico nas biografias destes dois heróis. Em relação a Coriolano, os pintores detiveram-se principalmente no momento em que o herói romano avançava sobre Roma à frente do exército volsco e é persuadido a não atacar a cidade por um grupo suplicantes matronas romanas, entre as quais estava a sua mãe e a sua mulher ${ }^{35}$. O tema eleito para Alexandre da Macedónia é a protecção que presta à família do Imperador persa Dario (mãe, mulher e irmã), depois da derrota deste em batalha contra os helenos e da sua morte ${ }^{36}$. Nos dois casos, aquilo que os pintores pretenderam destacar é evidente, uma das qualidades do bom governante, a clemência. De resto, as pinturas alusivas à figura de Alexandre são como que a enumeração das qualidades a um monarca exemplar, enquanto militar (Entrada de Alexandre em Babilónia, Charles Le Brun, c. 1664 ${ }^{37}$ ),

${ }^{35}$ Plutarco, Coriolano 33-36.

${ }^{36}$ Plutarco, Alexandre 21.

${ }^{37}$ Cf. Plutarco, Alexandre 35. 
chefe de família e herdeiro de um património cultural (Alexandre, o Grande e Roxana perante 0 túmulo de Aquiles, Pietro Antonio Rotari, 1756 $6^{38}$ ) e patrono das artes e da cultura (Alexandre, o Grande e Campaspe no estúdio de Apeles, Giovanni Battista Tiepolo, 1725-1726639; Diógenes e Alexandre, Giovanni Battista Langetti, c. $1650^{40}$ ). Tendo em conta que a maioria das obras protagonizadas por Alexandre data dos séculos XVII e XVIII, não podemos deixar de relacionar esta construção da imagem do rei ideal com a construção do Estado moderno e a figura do déspota esclarecido, que teve em Luís XIV da França um dos seus epítomes.

Voltemos ainda a Coriolano para nos determos na obra Coriolano perante a súplica de sua mãe (1650) de Nicolas Poussin ${ }^{41}$, exemplar quanto à relação da narratividade artística com a narrativa biográfica de Plutarco. O mote da narrativa de Plutarco é o discurso da mãe dirigido ao filho, revoltado contra a sua pátria, e que livra Roma da cólera de Coriolano. $\mathrm{O}$ pintor francês realizou um interpretação plástica bastante fiel à descrição feita por Plutarco. As etapas temporais da narrativa são fundidas na densidade imóvel da acção dramática, coreografada como se tratasse de um baixo relevo. Organizando o quadro à volta da confrontação de Coriolano com a sua mãe, Poussin consegue transmitir a importância

\footnotetext{
${ }^{38}$ Cf. Plutarco, Alexandre 15.8-9.

${ }^{39}$ Cf. Plutarco, Alexandre 4.

${ }^{40}$ Cf. Plutarco, Alexandre 14.2-6.

${ }^{41}$ Cf. Plutarco, Coriolano 33-36.
} 
que Plutarco concede à palavra neste episódio que põe fim à revolta do militar romano pelo jogo dos gestos, pelas atitudes e pela articulação plástica entre as figuras ${ }^{42}$.

Regressemos então a Cleópatra, figura transversal à nossa cronologia, feito surpreendente se considerarmos, como dissemos atrás, que não é o objecto das biografias a que está associada - às de Júlio César e Marco António -, mas que na pintura se sobrepõe aos biografados por Plutarco no lugar de protagonista da acção. Por outro lado, há que lembrar que as Vidas Paralelas de Plutarco, pelos factos a que aludem, mesmo se secundariamente participadas por Cleópatra, não deixam de ser uma fonte imprescindível para conhecer a história da última rainha do Egipto. De qualquer modo, a constância com que a imagem de Cleópatra foi reaparecendo na pintura de história durante estes cinco séculos é demonstrativa do seu poder icónico.

Cleópatra é uma figura negativa, é-o na visão moral e ética que Plutarco tem da história e continua a sê-lo a partir do Renascimento, com Boccaccio a abrir a sua vida de Cleópatra no atrás citado $D e$ Mulieribus Claris afirmando que ela conquistou a sua glória por pouco mais que a sua beleza e que ficou conhecida no mundo pela sua ganância, crueldade e luxúria ${ }^{43}$. Mesmo a imagem mais favorável que os anos finais do século XIX empreendem está marcada pela

${ }^{42}$ Fumaroli (1994) 167-169.

${ }^{43}$ Hamer (2001) 302. 
faceta da mulher sedutora e manipuladora, mas que na altura fascinava a cultura simbolista e decadentista finessecular. Deve-se esta imagem à propaganda romana, devidamente mantida e prolongada pela historiografia, que a acusavam de seduzir Júlio César e depois Marco António para manter o trono do Egipto, provocando a impopularidade de ambos os generais romanos e a guerra civil com o segundo. Porquê então a popularidade do mito ao longo do tempo? A explicação parece estar na negatividade das tipologias temáticas com que a arte a imaginou, que têm o seu desfecho no trágico suicídio e que comportam um juízo de valor sobre as consequências dos comportamentos desviantes. Transportaram consigo, nas palavras de Mary Hamer, uma moralidade que pretendia restaurar uma determinada percepção da mulher, oposta ao que o comportamento da rainha egípcia significava ${ }^{44}$.

Os temas mais recorrentes são: César e Cleópatra ${ }^{45}$, os banquetes de Cleópatra ${ }^{46}$, os venenos de Cleópatra ${ }^{47}$, a morte de António ${ }^{48}$, a captura de Cleópatra $^{49}$ e a morte de Cleópatra ${ }^{50}$. Quanto à sua figuração, embora algumas das obras sejam inspiradas directamente nos acontecimentos narrados por Plutarco, são tratadas esquematicamente, sem ter em atenção alguns pormenores dos passos em causa. Outras

${ }^{44}$ Hamer (2001) 304.

${ }^{45}$ Plutarco, César 48.5; 49.

${ }^{46}$ Plutarco, António 28.

47 Plutarco, António 71.

${ }^{48}$ Plutarco, António 74.2-3; 76-78.1.

${ }^{49}$ Plutarco, António 79.

${ }^{50}$ Plutarco, António 84-86. 
ilustram particularidas referidas por Plutarco. Existem ainda aquelas que completam na representação algum aspecto só ligeiramente mencionado por Plutarco ou apenas suposto na situação descrita. A tipologia da morte de Cleópatra, tema de um grande número de obras, permite-nos confirmar a existência dessas possíveis variações. Pois, Plutarco nunca menciona que Cleópatra teria sido mordida no peito pela serpente que utilizou para suicidar-se, refere somente a existência de marcas no braço. A partir deste pormenor, foram realizadas obras em que Cleópatra surge apenas com as marcas no braço, a ser mordida no peito, com os sinais de ter sido mordida no peito e com uma serpente enrolada no braço, ou simplesmente com a serpente enrolada no braço.

São muitas as questões que ficaram por responder, as problemáticas por analisar, as temáticas por abordar e os significados por compreender, nos seus respectivos contextos históricos. No entanto, como afirmámos inicialmente, a reflexão que aqui terminamos corresponde a uma primeira abordagem de um percurso temático no tempo. Ficamos na expectativa das que se seguirão. 


\section{BibLIOGRAFIA}

Alberti, L. B. (1972), On Painting and on Sculpture. The Latin Texts of De Pictura and De Statua. Introd. C. Grayson. New York, Phaidon.

- - (1999), De la pintura y otros escritos sobre arte. Introd. R. de la Villa. Madrid, Editorial Tecnos.

BauzÁ, H. F. (2002), «Humanismo y Acciones en las Vidas de Plutarco" in Plutarco. Educador da Europa. Actas do Congresso. Porto, Fundação Eng. António de Almeida, 181-196.

Calinescu, M. (1999), As 5 Faces da Modernidade. Lisboa, Vega.

Checa, F., Morán, J. M. (1989), El Barroco. Madrid, Ediciones Istmo.

Emison, P. (1996), «Istoria [historia]» in J. Turner, ed., Grove, The Dictionary of Art, vol. 16. London, Macmillan Publishers, 613-615.

FAHY, E. (1971), «Tiepolo's Meeting of Antony and Cleopatra», The Burlington Magazine 113/825, 735-740.

Frazier, F. (1992), "Contribution à l'étude de la composition des "Vies" De Plutarque: l'élaboration des grandes scènes", $A N R W I I .33 .6$, 4488-4535. 
Frazier, F. (1996), Histoire et Morale dans les Vies parallèles de Plutarque. Paris, Les Belles Lettres.

Fumaroli, M. (1994), L'École du Silence. Le Sentiment des Images au XVIIe Siècle. Paris, Flammarion.

Geiger, J. (1996), «Cignaroli's Death of Cato and of Socrates», Zeitschrift für Kunstgeschichte 59/2, 270-278.

Grunchec, P. (1986), Le Peinture à L'École des Beaux-Arts. Les Concours des Prix de Rome (1797-1863), vol. I. [S.1.], École Nationale des Beaux-Arts.

Hamer, M. (2001), "The myth of Cleopatra since the Renaissance» in S. Walker, P. Higgs, eds., Cleopatra of Egypt. From History to Myth. London, The British Museum Press, 302-311.

Hedreen, G. (1994-1995), «SirLawrenceAlma-Tadema’s Women of Amphissa», The Journal of the Walters Art Gallery 52/53, 79-92.

Holanda, F. de (1984a), Da Pintura Antiga. Lisboa, Imprensa Nacional - Casa da Moeda.

__ de (1984b), Diálogos em Roma. Lisboa, Livros Horizonte.

Hughes-Hallett, L. (1990), Cleopatra. Histories, Dreams and Distortions. London, Pimlico. 
Knox, G. (1974), «Giambattista Tiepolo: Variations on the Theme of Anthony and Cleopatra», Master Drawings 12/4, 378-390.

LACY, P. de (1952), «Biography and Tragedy in Plutarch», AJPh 73/2, 159-171.

Lopes, R. O. (2003), «A Função da Imagem Artística Segundo a tradição medieval da Igreja e a prática da pintura portuguesa do Renascimento», Arte Teoria 9, 35-52.

Nieto Alcaide, V., Checa, F. (1993), El Renacimiento. Madrid, Ediciones Istmo.

Pérez Jiménez, A. (1990), «Plutarco y el Humanismo Español del Renacimiento» in A. Pérez Jiménez, G. del Cerro Calderón, eds., Estudios sobre Plutarco: obra y tradición. Málaga, Sociedad Española de Plutarquistas, 229-247.

(2002), «Orientacionesyaproximaciónbibliográfica al proyecto "La recepción de Plutarco desde la Antigüedad hasta el siglo XVII" " in Plutarchus Redivivus. Memorandum del II Encuentro de la Red Temática de Plutarco (Málaga, 1415 de junio de 2001) y Propuesta de Proyectos aprobados. Málaga, Universidad de Málaga, 27-71.

—_ (2002), Plutarchus Rediuiuus. Memorándum del II Encuentro de la Red Temática de Plutarco (Málaga, 14-15 de junio de 2001) y Propuesta 
de Proyectos Aprobados. Málaga, Universidad de Málaga.

ReID, J. D. (1993), The Oxford Guide to Classical Mythology in the Arts, 1300-1990s, vol. I. New York/London, Oxford University Press.

Rodrigues, N. S. (2002), «Plutarco, Historiador dos Lágidas: o Caso de Cleópatra VII Filopator» in Plutarco. Educadorda Europa. Actas do Congresso. Porto, Fundação Eng. António de Almeida, 127-149.

Russell, D. A. (1973), Plutarch. London, Duckworth. Semler, L. E. (2003), «Inigo Jones, Capricious Ornament and Plutarch's Wise Man», Journal of the Warburg and Courtauld Institute 66, 123-142.

Stechow, W. (1945), "The Love of Antiochus with Stratonica in Art», The Art Bulletin 27, 221-237.

Turner, J. ed. (1996), «History Painting» in Grove, The Dictionary of Art, vol. 14. London, Macmillan Publishers, 581-589.

Urbini, S. (1993), "Il mito di Cleopatra. Motivi ed esiti della sua rinnovata fortuna fra Rinascimento e Barocco", Xenia Antiqua 2, 181-222.

VincI, L. da (1998), Tratado de Pintura. Madrid, Ediciones Akal. 
WALSH, L. (1999), "Charles Le Brun, "art dictator of France”» in G. Perry, C. Cunningham, Academies, Museums and Canons of Art. New Haven/London, Yale University Press, 86-123. 


\section{Anexo I}

\section{LISTAGEM DAS OBRAS DE TEMÁTICA BASEADA NAS Vidas Paralelas de Plutarco}

\begin{tabular}{|l|l|l|l|}
\hline Pintor & Título & Ano/Século & $\begin{array}{l}\text { Possível } \\
\text { fonte } \\
\text { plutarquiana }\end{array}$ \\
\hline AbBiATI, Filippo & $\begin{array}{l}\text { Coriolano persuadido } \\
\text { pela sua família a } \\
\text { poupar Roma }\end{array}$ & 1661 & $\begin{array}{l}\text { Vida de } \\
\text { Coriolano }\end{array}$ \\
\hline $\begin{array}{l}\text { AlMA--TADEMA, } \\
\text { Sir Lawrence }\end{array}$ & $\begin{array}{l}\text { Ontónio e Cleópatra, } \\
\text { Al a.C. }\end{array}$ & 1883 & $\begin{array}{l}\text { Vida de } \\
\text { António }\end{array}$ \\
\hline $\begin{array}{l}\text { AltDorfer, } \\
\text { Albrecht }\end{array}$ & $\begin{array}{l}\text { A Batalha de } \\
\text { Alexandre }\end{array}$ & 1529 & $\begin{array}{l}\text { Vida de } \\
\text { Alexandre }\end{array}$ \\
\hline $\begin{array}{l}\text { AmALTEO, } \\
\text { Pomponio }\end{array}$ & A morte de Catão & c. 1580 & $\begin{array}{l}\text { Vida de Catão } \\
\text { Menor }\end{array}$ \\
\hline $\begin{array}{l}\text { Anónimo } \\
\text { (Miniaturista } \\
\text { flamengo) }\end{array}$ & $\begin{array}{l}\text { História de } \\
\text { Alexandre, o Grande }\end{array}$ & $1450-1490$ & $\begin{array}{l}\text { Vida de } \\
\text { Alexandre }\end{array}$ \\
\hline $\begin{array}{l}\text { Anónimo } \\
\text { (discípulo de } \\
\text { Nicolas Poussin) }\end{array}$ & Cleópatra e Octávio & Séc. XVII & $\begin{array}{l}\text { Vida de } \\
\text { António }\end{array}$ \\
\hline
\end{tabular}




\begin{tabular}{|c|c|c|c|}
\hline Anónimo & $\begin{array}{l}\text { A Morte de António e } \\
\text { Cleópatra, iluminura } \\
\text { do manuscrito de } \\
\text { Boccaccio (ce), De } \\
\text { casibus uirorum } \\
\text { ilustrium, Des cas } \\
\text { des nobles hommes } \\
\text { et femmes, traduçáo } \\
\text { francesa de Laurent } \\
\text { de Premiierfait, vol. } \\
\text { II, fol. 190v. }\end{array}$ & $1460-1470$ & $\begin{array}{l}\text { Vida de } \\
\text { António }\end{array}$ \\
\hline $\begin{array}{l}\text { Anónimo } \\
\text { (pintor activo } \\
\text { em Veneza e } \\
\text { Emília no final } \\
\text { do século XVI) }\end{array}$ & $\begin{array}{l}\text { O Suicidio de } \\
\text { Cleópatra }\end{array}$ & c. 1580 & $\begin{array}{l}\text { Vida de } \\
\text { António }\end{array}$ \\
\hline $\begin{array}{l}\text { Assereto, } \\
\text { Gioacchino }\end{array}$ & O suícidio de Catão & c. 1639 & $\begin{array}{l}\text { Vida de Catão } \\
\text { Menor }\end{array}$ \\
\hline $\begin{array}{l}\text { BALESTRA, } \\
\text { Antonio }\end{array}$ & $\begin{array}{l}\text { Teseu descobre a } \\
\text { espada de seu pai }\end{array}$ & $\begin{array}{l}\text { sécs. } \\
\text { XVII-XVIII }\end{array}$ & Vida de Teseu \\
\hline $\begin{array}{l}\text { BARBIERI, } \\
\text { Giovanni } \\
\text { Francesco (dito } \\
\text { Le Guerchin) }\end{array}$ & $\begin{array}{l}\text { Cleópatra perante } \\
\text { Octávio Augusto }\end{array}$ & c. 1640 & $\begin{array}{l}\text { Vida de } \\
\text { António }\end{array}$ \\
\hline Batoni, Pompeo & $\begin{array}{l}\text { A Morte de Marco } \\
\text { António }\end{array}$ & 1763 & $\begin{array}{l}\text { Vida de } \\
\text { António }\end{array}$ \\
\hline $\begin{array}{l}\text { BEAUFORT, } \\
\text { JacquesAntoine }\end{array}$ & $\begin{array}{l}\text { O Juramento de } \\
\text { Bruto }\end{array}$ & 1771 & $\begin{array}{l}\text { Vida de Bruto } \\
\text { Vida de César }\end{array}$ \\
\hline $\begin{array}{l}\text { BeCCAFUmi, } \\
\text { Domenico }\end{array}$ & A morte de Catão & c. 1519 & $\begin{array}{l}\text { Vida de Catão } \\
\text { Menor }\end{array}$ \\
\hline $\begin{array}{l}\text { BisCAINO, } \\
\text { Bartolomeo }\end{array}$ & $\begin{array}{l}\text { Coriolano recebendo } \\
\text { as matronas romanas }\end{array}$ & c. 1725 & $\begin{array}{l}\text { Vida de } \\
\text { Coriolano }\end{array}$ \\
\hline BLANCHARD & $\begin{array}{l}\text { Marte e a Vestal } \\
\text { Virginia }\end{array}$ & c. 1630 & $\begin{array}{l}\text { Vida de } \\
\text { Rómulo (?) }\end{array}$ \\
\hline
\end{tabular}




\begin{tabular}{|c|c|c|c|}
\hline $\begin{array}{l}\text { BöCKLIN, } \\
\text { Arnold }\end{array}$ & A Morte de Cleópatra & 1872 & $\begin{array}{l}\text { Vida de } \\
\text { António }\end{array}$ \\
\hline $\begin{array}{l}\text { BöCKLIN, } \\
\text { Arnold }\end{array}$ & $\begin{array}{l}\text { A Morte de } \\
\text { Cleópatra }\end{array}$ & 1878 & $\begin{array}{l}\text { Vida de } \\
\text { António }\end{array}$ \\
\hline $\begin{array}{l}\text { BoISFREMONT, } \\
\text { Charles-Pompée le } \\
\text { Boulanger de }\end{array}$ & A Morte de Cleópatra & 18241828 & $\begin{array}{l}\text { Vida de } \\
\text { António }\end{array}$ \\
\hline Boisselier, Félix & $\begin{array}{l}\text { A Morte de } \\
\text { Demóstenes }\end{array}$ & 1805 & $\begin{array}{l}\text { Vida de } \\
\text { Nícias }\end{array}$ \\
\hline $\begin{array}{l}\text { BotTICELLI, } \\
\text { Sandro }\end{array}$ & $\begin{array}{l}\text { A História de } \\
\text { Lucrécia }\end{array}$ & $1496 / 1504$ & $\begin{array}{l}\text { Vida de } \\
\text { Publícola (?) }\end{array}$ \\
\hline $\begin{array}{l}\text { Bouchet, Louis } \\
\text { André Gabriel }\end{array}$ & $\begin{array}{l}\text { A morte de Catão de } \\
\text { Útica }\end{array}$ & 1797 & $\begin{array}{l}\text { Vida de Catão } \\
\text { Menor }\end{array}$ \\
\hline $\begin{array}{l}\text { Bouillon, } \\
\text { Pierre }\end{array}$ & $\begin{array}{l}\text { A morte de Catão de } \\
\text { Útica }\end{array}$ & 1797 & $\begin{array}{l}\text { Vida de Catão } \\
\text { Menor }\end{array}$ \\
\hline $\begin{array}{l}\text { Bourdon, } \\
\text { Sébastien }\end{array}$ & $\begin{array}{l}\text { O reencontro de } \\
\text { António e Cleópatra }\end{array}$ & c. 1645 & $\begin{array}{l}\text { Vida de } \\
\text { António }\end{array}$ \\
\hline $\begin{array}{l}\text { BrASCASSAT, } \\
\text { Jacques } \\
\text { Raymond }\end{array}$ & Coriolano e sua mãe & 1831 & $\begin{array}{l}\text { Vida de } \\
\text { Coriolano }\end{array}$ \\
\hline $\begin{array}{l}\text { BRISSET, Pierre- } \\
\text {-Nicolas }\end{array}$ & $\begin{array}{l}\text { A Partida de Gaio } \\
\text { Graco }\end{array}$ & 1840 & $\begin{array}{l}\text { Vida de Gaio } \\
\text { Graco }\end{array}$ \\
\hline $\begin{array}{l}\text { Brueghel, Jan } \\
\text { (o velho) }\end{array}$ & A Batalha de Isso & 1602 & $\begin{array}{l}\text { Vida de } \\
\text { Alexandre }\end{array}$ \\
\hline $\begin{array}{l}\text { BRUSASORCI, } \\
\text { Domenico }\end{array}$ & $\begin{array}{l}\text { O Suicídio de } \\
\text { Cleópatra }\end{array}$ & $1550 / 1555$ & $\begin{array}{l}\text { Vida de } \\
\text { António }\end{array}$ \\
\hline $\begin{array}{l}\text { CABANEL, } \\
\text { Alexandre }\end{array}$ & $\begin{array}{l}\text { Cleópatra ensaiando } \\
\text { os venenos nos } \\
\text { condenados à morte }\end{array}$ & 1887 & $\begin{array}{l}\text { Vida de } \\
\text { António }\end{array}$ \\
\hline $\begin{array}{l}\text { CaDES, } \\
\text { Giuseppe }\end{array}$ & $\begin{array}{l}\text { Alexandre, o Grande } \\
\text { recusa-se a beber água }\end{array}$ & 1792 & $\begin{array}{l}\text { Vida de } \\
\text { Alexandre }\end{array}$ \\
\hline $\begin{array}{l}\text { CAGNACCI, } \\
\text { Guido }\end{array}$ & Cleópatra & c. 1659 & $\begin{array}{l}\text { Vida de } \\
\text { António }\end{array}$ \\
\hline
\end{tabular}




\begin{tabular}{|c|c|c|c|}
\hline $\begin{array}{l}\text { CAGNACCI, } \\
\text { Guido }\end{array}$ & A Morte de Cleópatra & $\begin{array}{l}\text { c. } 659 / 1661 \\
/ 1662\end{array}$ & $\begin{array}{l}\text { Vida de } \\
\text { António }\end{array}$ \\
\hline $\begin{array}{l}\text { CAMUCCINI, } \\
\text { Vincenzo }\end{array}$ & $\begin{array}{l}\text { Os Idos de Março / A } \\
\text { morte de César }\end{array}$ & c. 1800 & Vida de César \\
\hline $\begin{array}{l}\text { CAMUCCINI, } \\
\text { Vincenzo }\end{array}$ & O Triunfo de César & c. 1800 & Vida de César \\
\hline $\begin{array}{l}\text { CAMUCCINI, } \\
\text { Vincenzo }\end{array}$ & $\begin{array}{l}\text { Rómulo e Remo } \\
\text { descobertos }\end{array}$ & c. 1800 & $\begin{array}{l}\text { Vida de } \\
\text { Rómulo }\end{array}$ \\
\hline Caravaggio & $\begin{array}{l}\text { Os sete actos de } \\
\text { misericórdia }\end{array}$ & 1607 & $\begin{array}{l}\text { Vida de } \\
\text { Numa (?) }\end{array}$ \\
\hline $\begin{array}{l}\text { Cignaroli, } \\
\text { Giambettino }\end{array}$ & A Morte de Catão & $\begin{array}{l}\text { Séc. XVII } \\
\text { (?) }\end{array}$ & $\begin{array}{l}\text { Vida de Catão } \\
\text { Menor }\end{array}$ \\
\hline Collier, John & A Morte de Cleópatra & 1890 & $\begin{array}{l}\text { Vida de } \\
\text { António }\end{array}$ \\
\hline $\begin{array}{l}\text { Conca, } \\
\text { Sebastiano }\end{array}$ & $\begin{array}{l}\text { Alexandre, o Grande } \\
\text { no Templo de } \\
\text { Jerusalém }\end{array}$ & $1735-1737$ & $\begin{array}{l}\text { Vida de } \\
\text { Alexandre (?) }\end{array}$ \\
\hline $\begin{array}{l}\text { CoRTona, Pietro } \\
\text { de }\end{array}$ & $\begin{array}{l}\text { O Rapto das } \\
\text { Mulheres Sabinas }\end{array}$ & $1627-1629$ & $\begin{array}{l}\text { Vida de } \\
\text { Rómulo }\end{array}$ \\
\hline $\begin{array}{l}\text { Cortona, Pietro } \\
\text { de }\end{array}$ & $\begin{array}{l}\text { Rómulo e Remo } \\
\text { acolhidos por } \\
\text { Fáustulo }\end{array}$ & c. 1643 & $\begin{array}{l}\text { Vida de } \\
\text { Rómulo }\end{array}$ \\
\hline $\begin{array}{l}\text { CozzA, } \\
\text { Francesco }\end{array}$ & $\begin{array}{l}\text { Cleópatra oferecendo- } \\
\text { se à morte }\end{array}$ & 1675 & $\begin{array}{l}\text { Vida de } \\
\text { António }\end{array}$ \\
\hline $\begin{array}{l}\text { Crayer, Gaspar } \\
\text { de }\end{array}$ & Alexandre e Diógenes & Séc. XVII & $\begin{array}{l}\text { Vida de } \\
\text { Alexandre }\end{array}$ \\
\hline $\begin{array}{l}\text { DAVID, } \\
\text { JacquesLouis }\end{array}$ & Antioco e Estratonice & 1774 & $\begin{array}{l}\text { Vida de } \\
\text { Demétrio }\end{array}$ \\
\hline $\begin{array}{l}\text { DAVID, } \\
\text { JacquesLouis }\end{array}$ & $\begin{array}{l}\text { Os lictores devolvendo } \\
\text { a Bruto os corpos de } \\
\text { seus filhos }\end{array}$ & 1789 & Vida de Bruto \\
\hline $\begin{array}{l}\text { DAVID, } \\
\text { JacquesLouis }\end{array}$ & $\begin{array}{l}\text { A Intervenção das } \\
\text { Mulheres Sabinas }\end{array}$ & 1799 & $\begin{array}{l}\text { Vida de } \\
\text { Rómulo }\end{array}$ \\
\hline
\end{tabular}




\begin{tabular}{|c|c|c|c|}
\hline $\begin{array}{l}\text { Dejussieu, } \\
\text { Henri Blaise } \\
\text { François }\end{array}$ & $\begin{array}{l}\text { Cleópatra ou } \\
\text { Cleópatra e a escrava }\end{array}$ & 1863 & $\begin{array}{l}\text { Vida de } \\
\text { António }\end{array}$ \\
\hline $\begin{array}{l}\text { DelaCroix, } \\
\text { Eugène }\end{array}$ & $\begin{array}{l}\text { Cleópatra eo } \\
\text { Camponês }\end{array}$ & 1838 & $\begin{array}{l}\text { Vida de } \\
\text { António }\end{array}$ \\
\hline $\begin{array}{l}\text { Diziani, } \\
\text { Gaspare }\end{array}$ & $\begin{array}{l}\text { A familia de Dario } \\
\text { perante Alexandre, o } \\
\text { Grande }\end{array}$ & Séc. XVIII & $\begin{array}{l}\text { Vida de } \\
\text { Alexandre }\end{array}$ \\
\hline DOMENICHINO & $\begin{array}{l}\text { Timocleia cativa } \\
\text { trazida perante } \\
\text { Alexandre }\end{array}$ & c. 1615 & $\begin{array}{l}\text { Vida de } \\
\text { Alexandre }\end{array}$ \\
\hline $\begin{array}{l}\text { DUPRÉ, } \\
\text { FrançoisXavier }\end{array}$ & $\begin{array}{l}\text { Coriolano na casa de } \\
\text { Tulo, rei dos Volscos }\end{array}$ & 1827 & $\begin{array}{l}\text { Vida de } \\
\text { Coriolano }\end{array}$ \\
\hline $\begin{array}{l}\text { Duvivier, } \\
\text { Johannes } \\
\text { Bernardus }\end{array}$ & $\begin{array}{l}\text { Cleópatra capturada } \\
\text { pelos soldados } \\
\text { romanos após a morte } \\
\text { de Marco António }\end{array}$ & 1789 & $\begin{array}{l}\text { Vida de } \\
\text { António }\end{array}$ \\
\hline $\begin{array}{l}\text { EECKOUT, } \\
\text { Gerbrand von } \\
\text { der }\end{array}$ & $\begin{array}{l}\text { Volúmnia perante } \\
\text { Coriolano }\end{array}$ & Séc. XVII & $\begin{array}{l}\text { Vida de } \\
\text { Coriolano }\end{array}$ \\
\hline $\begin{array}{l}\text { EvERDINGEN, } \\
\text { Caesar von }\end{array}$ & $\begin{array}{l}\text { Licurgo } \\
\text { demonstrando } \\
\text { os benefícios da } \\
\text { Educação }\end{array}$ & $1660-1662$ & $\begin{array}{l}\text { Vida de } \\
\text { Licurgo }\end{array}$ \\
\hline Ferrari, Luca & A Morte de Cleópatra & c. 1650 & $\begin{array}{l}\text { Vida de } \\
\text { António }\end{array}$ \\
\hline $\begin{array}{l}\text { FESELEN, } \\
\text { Melchior }\end{array}$ & $\begin{array}{l}\text { Alésia cercada por } \\
\text { Júlio César }\end{array}$ & Séc. XVI & Vida de César \\
\hline $\begin{array}{l}\text { FLANDRIN, } \\
\text { Hippolyte }\end{array}$ & $\begin{array}{l}\text { Teseu reconbecido por } \\
\text { seu pai }\end{array}$ & 1832 & Vida de Teseu \\
\hline $\begin{array}{l}\text { FONTANA, } \\
\text { Lavinia }\end{array}$ & Cleópatra & c. 1585 & $\begin{array}{l}\text { Vida de } \\
\text { António }\end{array}$ \\
\hline Foppa, Vicenzo & $\begin{array}{l}\text { A leitura do menino } \\
\text { Cícero }\end{array}$ & c. 1464 & $\begin{array}{l}\text { Vida de } \\
\text { Cícero }\end{array}$ \\
\hline
\end{tabular}




\begin{tabular}{|c|c|c|c|}
\hline FouQuet, Jean & $\begin{array}{l}\text { A fuga de Pompeio } \\
\text { depois da batalha de } \\
\text { Farsália }\end{array}$ & Séc. XV & $\begin{array}{l}\text { Vida de } \\
\text { Pompeio } \\
\text { Vida de César }\end{array}$ \\
\hline FOUQUET, Jean & $\begin{array}{l}\text { César atravessando o } \\
\text { Rubicão }\end{array}$ & Séc. XV & Vida de César \\
\hline Gauffier, Louis & $\begin{array}{l}\text { Rómulo em Remo em } \\
\text { casa de Fáustulo e } \\
\text { Aca Larência }\end{array}$ & Séc. XVIII & $\begin{array}{l}\text { Vida de } \\
\text { Rómulo }\end{array}$ \\
\hline Gauffier, Louis & $\begin{array}{l}\text { Entrevista de Augusto } \\
\text { e Cleópatra depois da } \\
\text { batalha de Áccio }\end{array}$ & 1788 & $\begin{array}{l}\text { Vida de } \\
\text { António }\end{array}$ \\
\hline $\begin{array}{l}\text { GeLlÉE, Claude } \\
\text { (dito Le Lorrain) }\end{array}$ & $\begin{array}{l}\text { O desembarque de } \\
\text { Cleópatra em Tarso } \\
\text { ou Páris e Helena } \\
\text { desembarcando em } \\
\text { Tróia }\end{array}$ & 1642 & $\begin{array}{l}\text { Vida de } \\
\text { António }\end{array}$ \\
\hline $\begin{array}{l}\text { GENGU, } \\
\text { Girolamo }\end{array}$ & $\begin{array}{l}\text { O filho de Fábio } \\
\text { Máximo resgatando } \\
\text { os prisioneiros de } \\
\text { Anibal }\end{array}$ & Séc. XVI & $\begin{array}{l}\text { Vida de Fábio } \\
\text { Máximo }\end{array}$ \\
\hline $\begin{array}{l}\text { GentilesChi, } \\
\text { Artemisa }\end{array}$ & Cleópatra & c. 1620 & $\begin{array}{l}\text { Vida de } \\
\text { António }\end{array}$ \\
\hline $\begin{array}{l}\text { GÉRÔME, } \\
\text { JeanLéon }\end{array}$ & A Morte de César & 1867 & Vida de César \\
\hline $\begin{array}{l}\text { GHIRLANDAIO, } \\
\text { Michele di } \\
\text { Ridolfo del }\end{array}$ & $\begin{array}{l}\text { O Suicidio de } \\
\text { Cleópatra }\end{array}$ & c. 1560 & $\begin{array}{l}\text { Vida de } \\
\text { António }\end{array}$ \\
\hline $\begin{array}{l}\text { Gianneti, } \\
\text { Raffaele }\end{array}$ & $\begin{array}{l}\text { O último senado de } \\
\text { Júlio César }\end{array}$ & 1867 & Vida de César \\
\hline $\begin{array}{l}\text { GRAVELOT, } \\
\text { Hubert François }\end{array}$ & Augusto e Cleópatra & Séc. XVIII & $\begin{array}{l}\text { Vida de } \\
\text { António }\end{array}$ \\
\hline Guercino & $\begin{array}{l}\text { Hersília separando } \\
\text { Rómulo de Tácio }\end{array}$ & 1645 & $\begin{array}{l}\text { Vida de } \\
\text { Rómulo }\end{array}$ \\
\hline $\begin{array}{l}\text { GUÉRIN, Pierre- } \\
\text {-Narcisse }\end{array}$ & $\begin{array}{l}\text { A morte de Catão de } \\
\text { Útica }\end{array}$ & 1797 & $\begin{array}{l}\text { Vida de Catão } \\
\text { Menor }\end{array}$ \\
\hline
\end{tabular}




\begin{tabular}{|c|c|c|c|}
\hline $\begin{array}{l}\text { GuÉRIN, Pierre- } \\
\text {-Narcisse }\end{array}$ & $\begin{array}{l}\text { O Casamento de } \\
\text { Alexandre, o Grande } \\
\text { e Roxana }\end{array}$ & Séc. XIX & $\begin{array}{l}\text { Vida de } \\
\text { Alexandre }\end{array}$ \\
\hline Hallé, Noël & $\begin{array}{l}\text { Cornélia mãe dos } \\
\text { Gracos }\end{array}$ & 1779 & $\begin{array}{l}\text { Vida Gaio } \\
\text { Graco } \\
\text { Vida de } \\
\text { Tibério Graco }\end{array}$ \\
\hline $\begin{array}{l}\text { HAMILTON, } \\
\text { Gavin }\end{array}$ & $\begin{array}{l}\text { O Juramento de } \\
\text { Bruto }\end{array}$ & $1763-1764$ & Vida de Bruto \\
\hline $\begin{array}{l}\text { HAMILTON, } \\
\text { Gavin }\end{array}$ & Cleópatra & $1767-1769$ & $\begin{array}{l}\text { Vida de } \\
\text { António }\end{array}$ \\
\hline $\begin{array}{l}\text { Heim, François- } \\
\text {-Joseph }\end{array}$ & $\begin{array}{l}\text { Teseu vencedor do } \\
\text { Minotauro }\end{array}$ & 1807 & $\begin{array}{l}\text { Vida de Teseu } \\
\text { (?) }\end{array}$ \\
\hline $\begin{array}{l}\text { HILLEMACHER, } \\
\text { Eugéne Ernest }\end{array}$ & $\begin{array}{l}\text { António moribundo } \\
\text { levado até Cleópatra }\end{array}$ & 1863 & $\begin{array}{l}\text { Vida de } \\
\text { António }\end{array}$ \\
\hline $\begin{array}{l}\text { Hire, Laurent } \\
\text { de La }\end{array}$ & Teseu e Etra & $1635-1640$ & Vida de Teseu \\
\hline $\begin{array}{l}\text { Hire, Laurent } \\
\text { de La }\end{array}$ & $\begin{array}{l}\text { Cornélia recusa a } \\
\text { coroa de Ptolemeu }\end{array}$ & 1646 & $\begin{array}{l}\text { Vida de } \\
\text { Tibério Graco }\end{array}$ \\
\hline Hozt, Gérard & A Morte de Cleópatra & Séc. XVIII & $\begin{array}{l}\text { Vida de } \\
\text { António }\end{array}$ \\
\hline $\begin{array}{l}\text { HonTHORST, } \\
\text { Gerrit von }\end{array}$ & Solón e Creso & 1624 & Vida de Sólon \\
\hline $\begin{array}{l}\text { INGRES, Jean- } \\
\text {-Auguste }\end{array}$ & Antíoco e Estratonice & 1840 & $\begin{array}{l}\text { Vida de } \\
\text { Demétrio }\end{array}$ \\
\hline $\begin{array}{l}\text { JACOPO, } \\
\text { Giovanni } \\
\text { Battista } \\
\text { (dito Il Rosso } \\
\text { Fiorentino) }\end{array}$ & A Morte de Cleópatra & $1524-1527$ & $\begin{array}{l}\text { Vida de } \\
\text { António }\end{array}$ \\
\hline JORDAENS, Jacob & A Morte de Cleópatra & 1653 & $\begin{array}{l}\text { Vida de } \\
\text { António }\end{array}$ \\
\hline
\end{tabular}




\begin{tabular}{|c|c|c|c|}
\hline $\begin{array}{l}\text { KaUfFMANN, } \\
\text { Angelika }\end{array}$ & $\begin{array}{l}\text { Cleópatra decorando } \\
\text { o túmulo de Marco } \\
\text { António }\end{array}$ & $1769-1770$ & $\begin{array}{l}\text { Vida de } \\
\text { António }\end{array}$ \\
\hline Lacour, Pierre & $\begin{array}{l}\text { Cleópatra } \\
\text { lamentando-se no } \\
\text { túmulo de Marco } \\
\text { António }\end{array}$ & 1781 & $\begin{array}{l}\text { Vida de } \\
\text { António }\end{array}$ \\
\hline $\begin{array}{l}\text { LAIRESSE, Gérard } \\
\text { de }\end{array}$ & $\begin{array}{l}\text { O banquete de } \\
\text { Cleópatra }\end{array}$ & c. 1675 & $\begin{array}{l}\text { Vida de } \\
\text { António }\end{array}$ \\
\hline $\begin{array}{l}\text { LAIRESSE, Gérard } \\
\text { de }\end{array}$ & A Morte de Cleópatra & $1675-1680$ & $\begin{array}{l}\text { Vida de } \\
\text { António }\end{array}$ \\
\hline $\begin{array}{l}\text { LAIRESSE, Gérard } \\
\text { de }\end{array}$ & $\begin{array}{l}\text { O desembarque de } \\
\text { Cleópatra em Tarso } \\
\text { ou Páris e Helena } \\
\text { desembarcando em } \\
\text { Tróia }\end{array}$ & $1685-1690$ & $\begin{array}{l}\text { Vida de } \\
\text { António }\end{array}$ \\
\hline $\begin{array}{l}\text { LANGETTI, } \\
\text { Giovanni } \\
\text { Battista }\end{array}$ & Catão & $1660-1680$ & $\begin{array}{l}\text { Vida de Catão } \\
\text { Menor }\end{array}$ \\
\hline $\begin{array}{l}\text { LANGETTI, } \\
\text { Giovanni } \\
\text { Battista }\end{array}$ & Diógenes e Alexandre & c. 1650 & $\begin{array}{l}\text { Vida de } \\
\text { Alexandre }\end{array}$ \\
\hline $\begin{array}{l}\text { LARIVIÈRE, } \\
\text { Charles Philippe- } \\
\text {-Auguste }\end{array}$ & $\begin{array}{l}\text { A Morte de } \\
\text { Alcibiades }\end{array}$ & 1824 & $\begin{array}{l}\text { Vida de } \\
\text { Alcibiades }\end{array}$ \\
\hline $\begin{array}{l}\text { Le Brun, } \\
\text { Charles }\end{array}$ & $\begin{array}{l}\text { A familia de Dario } \\
\text { perante Alexandre }\end{array}$ & c. 1660 & $\begin{array}{l}\text { Vida de } \\
\text { Alexandre }\end{array}$ \\
\hline $\begin{array}{l}\text { Le Brun, } \\
\text { Charles }\end{array}$ & $\begin{array}{l}\text { Entrada de Alexandre } \\
\text { em Babilónia }\end{array}$ & c. 1664 & $\begin{array}{l}\text { Vida de } \\
\text { Alexandre }\end{array}$ \\
\hline $\begin{array}{l}\text { LE BRUn, } \\
\text { Charles }\end{array}$ & Alexandre e Poro & 1665 & $\begin{array}{l}\text { Vida de } \\
\text { Alexandre }\end{array}$ \\
\hline $\begin{array}{l}\text { LETHIÈRE, } \\
\text { Guillaume }\end{array}$ & $\begin{array}{l}\text { A morte de Catão em } \\
\text { Útica }\end{array}$ & 1795 & $\begin{array}{l}\text { Vida de Catão } \\
\text { Menor }\end{array}$ \\
\hline Liss, Johann & A Morte de Cleópatra & $1622-1624$ & $\begin{array}{l}\text { Vida de } \\
\text { António }\end{array}$ \\
\hline
\end{tabular}




\begin{tabular}{|c|c|c|c|}
\hline $\begin{array}{l}\text { Luçon, Mestre } \\
\text { de }\end{array}$ & $\begin{array}{l}\text { Banquete de } \\
\text { Cleópatra, } \\
\text { iluminura do } \\
\text { manuscrito de } \\
\text { Boccaccio (ce), Des } \\
\text { casibus virorum } \\
\text { ilustrium, Des cas } \\
\text { des nobles hommes } \\
\text { et femmes, tradução } \\
\text { francesa de Laurent } \\
\text { de Premiierfait, vol. } \\
\text { II, fol. } 26\end{array}$ & c. 1410 & $\begin{array}{l}\text { Vida de } \\
\text { António }\end{array}$ \\
\hline $\begin{array}{l}\text { Luçon, Mestre } \\
\text { de }\end{array}$ & $\begin{array}{l}\text { A Morte de António e } \\
\text { Cleópatra, iluminura } \\
\text { do manuscrito de } \\
\text { Boccaccio (ce), Des } \\
\text { casibus virorum } \\
\text { ilustrium, Des cas } \\
\text { des nobles hommes } \\
\text { et femmes, tradução } \\
\text { francesa de Laurent } \\
\text { de Premiierfait, vol. } \\
\text { II, fol. } 66\end{array}$ & c. 1410 & $\begin{array}{l}\text { Vida de } \\
\text { António }\end{array}$ \\
\hline MAKART, Hans & A Morte de Cleópatra & 1875 & $\begin{array}{l}\text { Vida de } \\
\text { António }\end{array}$ \\
\hline $\begin{array}{l}\text { MANTEGNA, } \\
\text { Andrea }\end{array}$ & O Triunfo de César & dp. 1486 & Vida de César \\
\hline $\begin{array}{l}\text { Mazzoni, } \\
\text { Sebastiano }\end{array}$ & A Morte de Cleópatra & 1660 & $\begin{array}{l}\text { Vida de } \\
\text { António }\end{array}$ \\
\hline $\begin{array}{l}\text { MÉNAGEOT, } \\
\text { François } \\
\text { Guillaume }\end{array}$ & $\begin{array}{l}\text { Cleópatra no túmulo } \\
\text { de Marco António }\end{array}$ & 1785 & $\begin{array}{l}\text { Vida de } \\
\text { António }\end{array}$ \\
\hline $\begin{array}{l}\text { Mengs, Anton } \\
\text { Raphael }\end{array}$ & Augusto e Cleópatra & 1759 & $\begin{array}{l}\text { Vida de } \\
\text { António }\end{array}$ \\
\hline $\begin{array}{l}\text { Mengs, Anton } \\
\text { Raphael }\end{array}$ & Augusto e Cleópatra & 1760 & $\begin{array}{l}\text { Vida de } \\
\text { António }\end{array}$ \\
\hline
\end{tabular}




\begin{tabular}{|c|c|c|c|}
\hline Mignard, Pierre & A Morte de Cleópatra & Séc. XVII & $\begin{array}{l}\text { Vida de } \\
\text { António }\end{array}$ \\
\hline $\begin{array}{l}\text { Moreau, } \\
\text { Gustave }\end{array}$ & $\begin{array}{l}\text { O Triunfo de } \\
\text { Alexandre, o Grande }\end{array}$ & c. 1885 & $\begin{array}{l}\text { Vida de } \\
\text { Alexandre }\end{array}$ \\
\hline $\begin{array}{l}\text { Natoire, } \\
\text { CharlesJoseph }\end{array}$ & $\begin{array}{l}\text { O reencontro de } \\
\text { Marco António e } \\
\text { Cleópatra em Tarso }\end{array}$ & $1741-1755$ & $\begin{array}{l}\text { Vida de } \\
\text { António }\end{array}$ \\
\hline $\begin{array}{l}\text { Natoire, } \\
\text { CharlesJoseph }\end{array}$ & $\begin{array}{l}\text { O Banquete de } \\
\text { Cleópatra e Marco } \\
\text { António }\end{array}$ & 1754 & $\begin{array}{l}\text { Vida de } \\
\text { António }\end{array}$ \\
\hline $\begin{array}{l}\text { Natoire, } \\
\text { CharlesJoseph }\end{array}$ & $\begin{array}{l}\text { A chegada de } \\
\text { Cleópatra a Tarso }\end{array}$ & 1756 & $\begin{array}{l}\text { Vida de } \\
\text { António }\end{array}$ \\
\hline Negroni, Pietro & $\begin{array}{l}\text { O Sucídio de } \\
\text { Cleópatra }\end{array}$ & c. 1545 & $\begin{array}{l}\text { Vida de } \\
\text { António }\end{array}$ \\
\hline $\begin{array}{l}\text { Nouy, Jean } \\
\text { Lecomte du }\end{array}$ & $\begin{array}{l}\text { Demóstenes } \\
\text { praticando a oratória }\end{array}$ & 1870 & $\begin{array}{l}\text { Vida de } \\
\text { Alexandre (?) }\end{array}$ \\
\hline $\begin{array}{l}\text { ODEVAËRE, } \\
\text { JosephDenis }\end{array}$ & $\begin{array}{l}\text { A morte de Fócion ou } \\
\text { Catão }\end{array}$ & 1804 & $\begin{array}{l}\text { Vida de } \\
\text { Fócion } \\
\text { Vida de Catão } \\
\text { Menor }\end{array}$ \\
\hline Pauwel, Pieter & Rómulo e Remo & $1615-1616$ & $\begin{array}{l}\text { Vida de } \\
\text { Rómulo }\end{array}$ \\
\hline $\begin{array}{l}\text { Perugino, } \\
\text { Pietro }\end{array}$ & Catão & $1497-1500$ & $\begin{array}{l}\text { Vida de Catão } \\
\text { Menor }\end{array}$ \\
\hline $\begin{array}{l}\text { Piazzetta, } \\
\text { Giovanni } \\
\text { Battista }\end{array}$ & A Morte de Dario & c. 1746 & $\begin{array}{l}\text { Vida de } \\
\text { Alexandre }\end{array}$ \\
\hline Poussin, Nicolas & $\begin{array}{l}\text { O Rapto das } \\
\text { Mulheres Sabinas }\end{array}$ & $1634-1635$ & $\begin{array}{l}\text { Vida de } \\
\text { Rómulo }\end{array}$ \\
\hline Poussin, Nicolas & $\begin{array}{l}\text { O Rapto das } \\
\text { Mulheres Sabinas }\end{array}$ & $1637-1638$ & $\begin{array}{l}\text { Vida de } \\
\text { Rómulo }\end{array}$ \\
\hline Poussin, Nicolas & $\begin{array}{l}\text { Coriolano perante a } \\
\text { súplica de sua mãe }\end{array}$ & 1650 & $\begin{array}{l}\text { Vida de } \\
\text { Coriolano }\end{array}$ \\
\hline
\end{tabular}




\begin{tabular}{|c|c|c|c|}
\hline $\begin{array}{l}\text { Pujol, } \\
\text { Alexandre Denis } \\
\text { Abel de }\end{array}$ & A clemência de César & 1808 & $\begin{array}{l}\text { Vida de César } \\
\text { (?) }\end{array}$ \\
\hline $\begin{array}{l}\text { Pujol, } \\
\text { Alexandre Denis } \\
\text { Abel de }\end{array}$ & $\begin{array}{l}\text { Licurgo apresenta } \\
\text { aos Lacedemónios o } \\
\text { herdeiro do trono }\end{array}$ & 1811 & $\begin{array}{l}\text { Vida de } \\
\text { Licurgo }\end{array}$ \\
\hline $\begin{array}{l}\text { Pulgo, } \\
\text { Domenico }\end{array}$ & A Morte de Cleópatra & $\begin{array}{l}\text { Sécs. XV- } \\
\text { XVI }\end{array}$ & $\begin{array}{l}\text { Vida de } \\
\text { António }\end{array}$ \\
\hline $\begin{array}{l}\text { Regnault, } \\
\text { JeanBaptiste }\end{array}$ & $\begin{array}{l}\text { Diógenes visitado por } \\
\text { Alexandre }\end{array}$ & 1776 & $\begin{array}{l}\text { Vida de } \\
\text { Alexandre }\end{array}$ \\
\hline $\begin{array}{l}\text { Regnault, } \\
\text { JeanBaptiste }\end{array}$ & A Morte de Cleópatra & $\begin{array}{l}\text { c. } 1796- \\
1797\end{array}$ & $\begin{array}{l}\text { Vida de } \\
\text { António }\end{array}$ \\
\hline ReNI, Guido & Cleópatra e a áspide & c. 1630 & $\begin{array}{l}\text { Vida de } \\
\text { António }\end{array}$ \\
\hline Reni, Guido & A Morte de Cleópatra & $1625-1626$ & $\begin{array}{l}\text { Vida de } \\
\text { António }\end{array}$ \\
\hline RenI, Guido & $\begin{array}{l}\text { O Suicídio de } \\
\text { Cleópatra }\end{array}$ & $1639-1640$ & $\begin{array}{l}\text { Vida de } \\
\text { António }\end{array}$ \\
\hline $\begin{array}{l}\text { Ricci, } \\
\text { Sebastiano }\end{array}$ & $\begin{array}{l}\text { Infância de Rómulo } \\
\text { e Remo ou Rómulo } \\
\text { em Remo em casa } \\
\text { de Faustulo e Aca } \\
\text { Larencia }\end{array}$ & c. 1708 & $\begin{array}{l}\text { Vida de } \\
\text { Rómulo }\end{array}$ \\
\hline Rivalz, Antoine & A Morte de Cleópatra & Séc. XVIII & $\begin{array}{l}\text { Vida de } \\
\text { António }\end{array}$ \\
\hline Rivalz, Antoine & Cleópatra & Séc. XVIII & $\begin{array}{l}\text { Vida de } \\
\text { António }\end{array}$ \\
\hline $\begin{array}{l}\text { Rixens, Jean } \\
\text { André }\end{array}$ & A Morte de Cleópatra & 1874 & $\begin{array}{l}\text { Vida de } \\
\text { António }\end{array}$ \\
\hline Robert, Hubert & $\begin{array}{l}\text { Capriccio de } \\
\text { Templo Romano. } \\
\text { Entrada Triunfal de } \\
\text { Alexandre, o Grande }\end{array}$ & $1755-1760$ & $\begin{array}{l}\text { Vida de } \\
\text { Alexandre }\end{array}$ \\
\hline
\end{tabular}




\begin{tabular}{|c|c|c|c|}
\hline Romano, Giulio & Imperador Alexandre & 1532 & $\begin{array}{l}\text { Vida de } \\
\text { Alexandre }\end{array}$ \\
\hline $\begin{array}{l}\text { Rotari, Pietro } \\
\text { Antonio }\end{array}$ & $\begin{array}{l}\text { Alexandre, o Grande } \\
\text { e Roxana perante o } \\
\text { túmulo de Aquiles }\end{array}$ & 1756 & $\begin{array}{l}\text { Vida de } \\
\text { Alexandre }\end{array}$ \\
\hline $\begin{array}{l}\text { Royer, Lionel- } \\
\text {-Nöel }\end{array}$ & $\begin{array}{l}\text { Vercingétorix rende-se } \\
\text { a César }\end{array}$ & 1899 & Vida de César \\
\hline $\begin{array}{l}\text { Rubens, Pieter } \\
\text { Paul }\end{array}$ & $\begin{array}{l}\text { Rómulo e Remo em } \\
\text { crianças }\end{array}$ & 1614 & $\begin{array}{l}\text { Vida de } \\
\text { Rómulo }\end{array}$ \\
\hline $\begin{array}{l}\text { Rubens, Pieter } \\
\text { Paul }\end{array}$ & Marte e Reia Silvia & $1616-1617$ & $\begin{array}{l}\text { Vida de } \\
\text { Rómulo }\end{array}$ \\
\hline $\begin{array}{l}\text { Rubens, Pieter } \\
\text { Paul }\end{array}$ & $\begin{array}{l}\text { Batalha das } \\
\text { Amazonas }\end{array}$ & 1618 & $\begin{array}{l}\text { Vida de Teseu } \\
\text { (?) }\end{array}$ \\
\hline $\begin{array}{l}\text { Rubens, Pieter } \\
\text { Paul }\end{array}$ & O Rapto das Sabinas & $1635-1637$ & $\begin{array}{l}\text { Vida de } \\
\text { Rómulo }\end{array}$ \\
\hline $\begin{array}{l}\text { Sarto, Andrea } \\
\text { del }\end{array}$ & O Triunfo de César & c. 1520 & Vida de César \\
\hline $\begin{array}{l}\text { SCHÖNFELD, } \\
\text { Johann Heinrich }\end{array}$ & $\begin{array}{l}\text { Alexandre, o Grande } \\
\text { perante o túmulo de } \\
\text { Aquiles }\end{array}$ & c. 1630 & $\begin{array}{l}\text { Vida de } \\
\text { Alexandre }\end{array}$ \\
\hline $\begin{array}{l}\text { SCHÖNFELD, } \\
\text { Johann Heinrich }\end{array}$ & $\begin{array}{l}\text { O Rapto das } \\
\text { Mulheres Sabinas }\end{array}$ & $1630-1650$ & $\begin{array}{l}\text { Vida de } \\
\text { Rómulo }\end{array}$ \\
\hline $\begin{array}{l}\text { SigNORELLI, } \\
\text { Luca }\end{array}$ & $\begin{array}{l}\text { Coriolano persuadido } \\
\text { pela sua familia a } \\
\text { poupar Roma }\end{array}$ & c. 1509 & $\begin{array}{l}\text { Vida de } \\
\text { Coriolano }\end{array}$ \\
\hline Sodoma II & $\begin{array}{l}\text { O Rapto das } \\
\text { Mulheres Sabinas }\end{array}$ & $1506-1507$ & $\begin{array}{l}\text { Vida de } \\
\text { Rómulo }\end{array}$ \\
\hline Sodoma II & $\begin{array}{l}\text { As mulheres da } \\
\text { familia de Dario } \\
\text { perante Alexandre, o } \\
\text { Grande }\end{array}$ & c. 1517 & $\begin{array}{l}\text { Vida de } \\
\text { Alexandre }\end{array}$ \\
\hline Sodoma II & $\begin{array}{l}\text { O Casamento de } \\
\text { Alexandre e Roxana }\end{array}$ & c. 1517 & $\begin{array}{l}\text { Vida de } \\
\text { Alexandre }\end{array}$ \\
\hline
\end{tabular}




\begin{tabular}{|c|c|c|c|}
\hline Steen, Jan & $\begin{array}{l}\text { O Banquete de } \\
\text { António e Cleópatra }\end{array}$ & $1668-1669$ & $\begin{array}{l}\text { Vida de } \\
\text { António }\end{array}$ \\
\hline $\begin{array}{l}\text { STOMER, } \\
\text { Matthias }\end{array}$ & A Morte de Catão & Séc. XVII & $\begin{array}{l}\text { Vida de Catão } \\
\text { Menor }\end{array}$ \\
\hline $\begin{array}{l}\text { STOMER, } \\
\text { Matthias }\end{array}$ & $\begin{array}{l}\text { Catão tirando a } \\
\text { venda }\end{array}$ & Séc. XVII & $\begin{array}{l}\text { Vida de Catão } \\
\text { Menor }\end{array}$ \\
\hline $\begin{array}{l}\text { STROZZI, } \\
\text { Bernardo }\end{array}$ & $\begin{array}{l}\text { Alexandre, o Grande } \\
\text { restaurando o } \\
\text { trono usurpado a } \\
\text { Abdolomino }\end{array}$ & Séc. XVI & $\begin{array}{l}\text { Vida de } \\
\text { Alexandre (?) }\end{array}$ \\
\hline $\begin{array}{l}\text { Tiepolo, } \\
\text { Giovanni } \\
\text { Battista }\end{array}$ & $\begin{array}{l}\text { Alexandre, o Grande } \\
\text { e Campaspe no } \\
\text { estúdio de Apeles }\end{array}$ & $1725-1726$ & $\begin{array}{l}\text { Vida de } \\
\text { Alexandre (?) }\end{array}$ \\
\hline $\begin{array}{l}\text { Tiepolo, } \\
\text { Giovanni } \\
\text { Battista } \\
\end{array}$ & $\begin{array}{l}\text { Alexandre, o Grande } \\
\text { e Campaspe no } \\
\text { estúdio de Apeles }\end{array}$ & 1740 & $\begin{array}{l}\text { Vida de } \\
\text { Alexandre }\end{array}$ \\
\hline $\begin{array}{l}\text { Tiepolo, } \\
\text { Giovanni } \\
\text { Battista }\end{array}$ & Coriolano & c. 1730 & $\begin{array}{l}\text { Vida de } \\
\text { Coriolano }\end{array}$ \\
\hline $\begin{array}{l}\text { Tiepolo, } \\
\text { Giovanni } \\
\text { Battista }\end{array}$ & $\begin{array}{l}\text { A familia de Dario } \\
\text { perante Alexandre, o } \\
\text { Grande }\end{array}$ & 1743 & $\begin{array}{l}\text { Vida de } \\
\text { Alexandre }\end{array}$ \\
\hline $\begin{array}{l}\text { Tiepolo, } \\
\text { Giovanni } \\
\text { Battista }\end{array}$ & $\begin{array}{l}\text { O Banquete de } \\
\text { Cleópatra }\end{array}$ & $1743-1744$ & $\begin{array}{l}\text { Vida de } \\
\text { António }\end{array}$ \\
\hline $\begin{array}{l}\text { Tiepolo, } \\
\text { Giovanni } \\
\text { Battista }\end{array}$ & $\begin{array}{l}\text { O Banquete de } \\
\text { Cleópatra }\end{array}$ & $1746-1747$ & $\begin{array}{l}\text { Vida de } \\
\text { António }\end{array}$ \\
\hline $\begin{array}{l}\text { Tiepolo, } \\
\text { Giovanni } \\
\text { Battista } \\
\end{array}$ & $\begin{array}{l}\text { O reencontro de } \\
\text { António e Cleópatra }\end{array}$ & $1746-1747$ & $\begin{array}{l}\text { Vida de } \\
\text { António }\end{array}$ \\
\hline $\begin{array}{l}\text { Tiepolo, } \\
\text { Giovanni } \\
\text { Battista }\end{array}$ & $\begin{array}{l}\text { Alexandre, o Grande } \\
\text { com a mulher de } \\
\text { Dario }\end{array}$ & $1750-1753$ & $\begin{array}{l}\text { Vida de } \\
\text { Alexandre }\end{array}$ \\
\hline
\end{tabular}




\begin{tabular}{|c|c|c|c|}
\hline Tintoretto & $\begin{array}{l}\text { A libertação de } \\
\text { Arsinoe }\end{array}$ & c. 1556 & $\begin{array}{l}\text { Vida de } \\
\text { Demétrio (?) }\end{array}$ \\
\hline $\begin{array}{l}\text { Tischbein, } \\
\text { Johann Heinrich } \\
\text { (o Antigo) }\end{array}$ & $\begin{array}{l}\text { António moribundo } \\
\text { junto de Cleópatra }\end{array}$ & $1767-1769$ & $\begin{array}{l}\text { Vida de } \\
\text { António }\end{array}$ \\
\hline $\begin{array}{l}\text { Tischbein, } \\
\text { Johann Heinrich } \\
\text { (o Antigo) }\end{array}$ & $\begin{array}{l}\text { Augusto à cabeceira } \\
\text { de Cleópatra } \\
\text { moribunda }\end{array}$ & 1769 & $\begin{array}{l}\text { Vida de } \\
\text { António }\end{array}$ \\
\hline $\begin{array}{l}\text { Tischbein, } \\
\text { Johann Heinrich } \\
\text { (o Antigo) }\end{array}$ & António e Cleópatra & 1774 & $\begin{array}{l}\text { Vida de } \\
\text { António }\end{array}$ \\
\hline $\begin{array}{l}\text { Topino- } \\
\text {-Lebrun, Jean- } \\
\text {-Baptiste }\end{array}$ & $\begin{array}{l}\text { A morte de Gaio } \\
\text { Graco }\end{array}$ & 1792 & $\begin{array}{l}\text { Vida de Gaio } \\
\text { Graco }\end{array}$ \\
\hline UcCello, Paolo & O Triunfo de César & Séc. XV & Vida de César \\
\hline $\begin{array}{l}\text { ULMANN, } \\
\text { Benjamin }\end{array}$ & $\begin{array}{l}\text { Coriolano em casa de } \\
\text { Tulo, rei dos Volscos }\end{array}$ & 1859 & $\begin{array}{l}\text { Vida de } \\
\text { Coriolano }\end{array}$ \\
\hline $\begin{array}{l}\text { Verona, } \\
\text { Michele de }\end{array}$ & $\begin{array}{l}\text { Coriolano persuadido } \\
\text { pela sua família a } \\
\text { poupar Roma }\end{array}$ & $1495-1510$ & $\begin{array}{l}\text { Vida de } \\
\text { Coriolano }\end{array}$ \\
\hline Veronese, Paolo & $\begin{array}{l}\text { A familia de Dario } \\
\text { perante Alexandre }\end{array}$ & $1565-1570$ & $\begin{array}{l}\text { Vida de } \\
\text { Alexandre }\end{array}$ \\
\hline $\begin{array}{l}\text { VerRochio, } \\
\text { Andrea del }\end{array}$ & A Batalha de Pidna & c. 1475 & $\begin{array}{l}\text { Vida de Paulo } \\
\text { Emilio }\end{array}$ \\
\hline Vignon, Claude & A Morte de Cleópatra & Séc. XVII & $\begin{array}{l}\text { Vida de } \\
\text { António }\end{array}$ \\
\hline $\begin{array}{l}\text { VLEUGHELS, } \\
\text { Nicolas }\end{array}$ & $\begin{array}{l}\text { Apeles pintando uma } \\
\text { paisagem }\end{array}$ & 1756 & $\begin{array}{l}\text { Vida de } \\
\text { Demétrio (?) } \\
\text { Vida de } \\
\text { Alexandre (?) }\end{array}$ \\
\hline Vos, Marten de & $\begin{array}{l}\text { O Tribunal de } \\
\text { Brabant Mint em } \\
\text { Antuérpia }\end{array}$ & 1594 & \\
\hline
\end{tabular}




\section{AneXo II}

\section{DisTRIBUIÇÁ̃O DAS PINTURAS \\ LEVANTADAS POR CENTÚRIAS}

\section{Século XV}

Fouquet, Jean, A fuga de Pompeio depois da batalha de Farsália, séc. XV.

FouQueT, Jean, César atravessando o Rubicão, séc. XV.

Uccello, Paolo, O Triunfo de César, séc. XV.

Luçon, Mestre de, Banquete de Cleópatra, iluminura do manuscrito de Boccaccio (ce), De casibus uirorum ilustrium, Des cas des nobles hommes et femmes, tradução francesa de Laurent de Premiierfait, vol. II, fol. 26, c. 1410 .

Luçon, Mestre de, A Morte de António e Cleópatra, iluminura do manuscrito de Boccaccio (ce), Des casibus virorum ilustrium, Des cas des nobles hommes et femmes, tradução francesa de Laurent de Premiierfait, vol. II, fol. 66, c. 1410.

Anónimo (Miniaturista flamengo), História de Alexandre, o Grande, 1450-1490.

Anónimo, A Morte de António e Cleópatra, iluminura do manuscrito de Boccaccio (ce), Des casibus virorum ilustrium, Des cas des nobles hommes et femmes, tradução francesa de Laurent de Premiierfait, vol. II, fol. 190v, 1460-1470. 
Foppa, Vicenzo, A leitura do menino Cícero, c. 1464.

Verrochio, Andrea del, A Batalha de Pidna, c. 1475.

Mantegna, Andrea, O Triunfo de César, dp. 1486.

Verona, Michele de, Coriolano persuadido pela sua família a poupar Roma, 1495-1510.

Botticelli, Sandro, A História de Lucrécia, 1496-1504.

Perugino, Pietro, Catão, 1497-1500.

Pulgo, Domenico, A Morte de Cleópatra, séc. XV-XVI.

\section{Século XVI}

Feselen, Melchior, Alésia cercada por Júlio César, séc. XVI.

Gengu, Girolamo, O filho de Fábio Máximo resgatando os prisioneiros de Anibal, séc. XVI.

Strozzi, Bernardo, Alexandre o Grande restaurando o trono usurpado a Abdolomino, séc. XVI.

Sodoma II, O Rapto das Mulheres Sabinas, 1506-1507.

Sodoma II, As mulheres da família de Dario perante Alexandre, o Grande, c. 1517.

Sodoma II, O Casamento de Alexandre e Roxana, c. 1517.

Signorelli, Luca, Coriolano persuadido pela sua familia a poupar Roma, c. 1509.

Beccafumi, Domenico, A morte de Catão, c. 1519.

SARTo, Andrea del, O Triunfo de César, c. 1520. 
JaCopo, Giovanni Battista (dito Il Rosso Fiorentino), A Morte de Cleópatra, 1524-1527.

Altdorfer, Albrecht, A Batalha de Alexandre, 1529.

Romano, Giulio, Imperador Alexandre, 1532.

Negroni, Pietro, O Sucídio de Cleópatra, c. 1545.

Brusasorci, Domenico, O Suicídio de Cleópatra, 1550-1555.

Ghirlandaio, Michele di Ridolfo del, O Suicídio de Cleópatra, c. 1560.

Veronese, Paolo, A familia de Dario perante Alexandre, 1565-1570.

Amalteo, Pomponio - A morte de Catão, c. 1580.

Anónimo (pintor activo em Veneza e Emília no final do século XVI), O Suicídio de Cleópatra, c. 1580 .

Fontana, Lavinia, Cleópatra, c. 1585.

Vos, Marten de, O Tribunal de Brabant Mint em Antuérpia, 1594.

\section{SÉculo XVII}

Anónimo (discip. Nicolas Poussin), Cleópatra $e$ Octávio, séc. XVII.

Crayer, Gaspar de, Alexandre e Diógenes, séc. XVII.

Eecкоuт, Gerbrand von der, Volúmnia perante Coriolano, séc. XVII. 
Mignard, Pierre, A Morte de Cleópatra, séc. XVII.

Stomer, Matthias, A Morte de Catão, séc. XVII.

Stomer, Matthias, Catão tirando a venda, séc. XVII.

Vignon, Claude, A Morte de Cleópatra, séc. XVII.

Cignaroli, Giambettino, A Morte de Catão, séc. XVII?

Brueghel, Jan (o velho), A Batalha de Isso, 1602.

Caravaggio, Os sete actos de misericórdia, 1607.

Rubens, Pieter Paul, Rómulo e Remo em crianças, 1614.

Domenichino, Timocleia cativa trazida perante Alexandre, c. 1615.

Pauwel, Pieter, Rómulo e Remo, 1615-1616.

Rubens, Pieter Paul, Marte e Reia Silvia, 1616-1617.

Rubens, Pieter Paul, Batalha das Amazonas, 1618.

Gentileschi, Artemisa, Cleópatra, c. 1620.

Liss, Johann, A Morte de Cleópatra, 1622-1624.

Honthorst, Gerrit von, Solón e Creso, 1624.

Reni, Guido, A Morte de Cleópatra, 1625-1626.

Cortona, Pietro de, O Rapto das Mulheres Sabinas, 1627-1629.

Blanchard, Marte e a Vestal Virginia, c. 1630.

Reni, Guido, Cleópatra e a áspide, c. 1630.

Schönfeld, Johann Heinrich, Alexandre, o Grande perante o túmulo de Aquiles, c. 1630. 
Schönfeld, Johann Heinrich, O Rapto das Mulheres Sabinas, 1630-1650.

Poussin, Nicolas, O Rapto das Mulheres Sabinas, 1634-1635.

Rubens, Pieter Paul, O Rapto das Sabinas, 1635-1637.

Poussin, Nicolas, O Rapto das Mulheres Sabinas, 1637-1638.

Hire, Laurent de La, Teseu e Aetra, 1635-1640.

Assereto, Gioacchino, O suicídio de Catão, c. 1639.

Reni, Guido, O Suicídio de Cleópatra, 1639-1640.

Barbieri, Giovanni Francesco (dito Le Guerchin), Cleópatra perante Octávio Augusto, c. 1640.

Gellée, Claude (dito Le Lorrain), O desembarque de Cleópatra em Tarso ou Páris e Helena desembarcando em Tróia, 1642.

Cortona, Pietro de, Rómulo e Remo acolhidos por Fáustulo, c. 1643.

Bourdon, Sébastien, $O$ reencontro de António e Cleópatra, c. 1645.

Guercino, Hersilia separando Rómulo de Tácio, 1645.

Hire, Laurent de La, Cornélia recusa a coroa de Ptolomeu, 1646.

Ferrari, Luca, A Morte de Cleópatra, c. 1650.

Langetti, Giovanni Battista, Diógenes e Alexandre, c. 1650 . 
Poussin, Nicolas, Coriolano perante a súplica de sua mãe, 1650.

Jordaens, Jacob, A Morte de Cleópatra, 1653.

Cagnacci, Guido, Cleópatra, c. 1659.

Cagnacci, Guido, A Morte de Cleópatra, c. 1659/1661-1662.

Le Brun, Charles, A familia de Dario perante Alexandre, c. 1660.

Mazzoni, Sebastiano, A Morte de Cleópatra, 1660.

Everdingen, Caesar von, Licurgo demonstrando os benefícios da Educação, 1660-1662.

Langetti, Giovanni Battista, Catão, 1660-1680.

АввіAті, Filippo, Coriolano persuadido pela sua familia a poupar Roma, 1661.

LE BRUn, Charles, Entrada de Alexandre em Babilónia, c. 1664 .

Le Brun, Charles, Alexandre e Poro, 1665.

Steen, Jan, O Banquete de António e Cleópatra, 1668-1669.

Cozza, Francesco, Cleópatra oferecendo-se à morte, 1675.

LAIresse, Gérard de, O banquete de Cleópatra, c. 1675.

LAIresSe, Gérard de, A Morte de Cleópatra, 1675-1680.

Lairesse, Gérard de, $O$ desembarque de Cleópatra em Tarso ou Páris e Helena desembarcando em Tróia, 1685-1690. 
Balestra, Antonio, Teseu descobre a espada de seu pai, séc. XVII-XVIII.

\section{Século XVIII}

Diziani, Gaspare, A familia de Dario perante Alexandre, o Grande, séc. XVIII.

Gauffier, Louis, Rómulo em Remo em casa de Fáustulo e Aca Larência, séc. XVIII.

Gravelot, Hubert François, Augusto e Cleópatra, séc. XVIII.

Hoet, Gérard, A Morte de Cleópatra, séc. XVIII.

Rivalz, Antoine, A Morte de Cleópatra, séc. XVIII.

Rivalz, Antoine, Cleópatra, séc. XVIII.

Ricci, Sebastiano, Infância de Rómulo e Remo ou Rómulo em Remo em casa de Faustulo e Aca Larencia, c. 1708.

Biscaino, Bartolomeo, Coriolano recebendo as matronas romanas, c. 1725 .

Tiepolo, Giovanni Battista, Alexandre, o Grande e Campaspe no estúdio de Apeles, 1725-1726.

Tiepolo, Giovanni Battista, Coriolano, c. 1730.

Tiepolo, Giovanni Battista, Alexandre, o Grande e Campaspe no estúdio de Apeles, 1740.

Tiepolo, Giovanni Battista, A família de Dario perante Alexandre, O Grande, 1743.

Tiepolo, Giovanni Battista, O Banquete de Cleópatra, 1743-1744. 
Tiepolo, Giovanni Battista, O Banquete de Cleópatra, 1746-1747.

Tiepolo, Giovanni Battista, O reencontro de António e Cleópatra, 1746-1747.

Tiepolo, Giovanni Battista, Alexandre, o Grande com a mulher de Dario, 1750-1753.

Vleughels, Nicolas, Apeles pintando uma paisagem, 1756.

Tischbein, Johann Heinrich (o Antigo), António moribundo junto de Cleópatra, 1767-1769.

Tischbein, Johann Heinrich (o Antigo), Augusto à cabeceira de Cleópatra moribunda, 1769.

Tischbein, Johann Heinrich (o Antigo), António e Cleópatra, 1774.

Conca, Sebastiano, Alexandre, o Grande no Templo de Jerusalém, 1735-1737.

Tiepolo, Giovanni Battista, Alexandre, o Grande e Campasge no estúdio de Apeles, 1740.

Tischbein, Johann Heinrich (o Antigo), António moribundo junto de Cleópatra, 1767-1769.

Tischbein, Johann Heinrich (o Antigo), Augusto à cabeceira de Cleópatra moribunda, 1769.

Natoire, Charles-Joseph, O reencontro de Marco António e Cleópatra em Tarso, 1741-1755.

Tiepolo, Giovanni Battista, A familia de Dario perante Alexandre, O Grande, 1743. 
Tiepolo, Giovanni Battista, O Banquete de Cleópatra, 1743-1744.

Piazzetta, Giovanni Battista, A Morte de Dario, c. 1746.

Tiepolo, Giovanni Battista, O Banquete de Cleópatra, 1746-1747.

Tiepolo, Giovanni Battista, O reencontro de António e Cleópatra, 1746-1747.

Tiepolo, Giovanni Battista, Alexandre, o Grande com a mulher de Dario, 1750-1753.

Natoire, Charles-Joseph, O Banquete de Cleópatra e Marco António, 1754.

Robert, Hubert, Capriccio de Templo Romano. Entrada Triunfal de Alexandre, o Grande, 1755-1760.

Rotari, Pietro Antonio, Alexandre, o Grande $e$ Roxana perante o túmulo de Aquiles, 1756

Natoire, Charles-Joseph, A chegada de Cleópatra a Tarso, 1756.

Vleughels, Nicolas, Apeles pintando uma paisagem, 1756.

Mengs, Anton Raphael, Augusto e Cleópatra, 1759.

Mengs, Anton Raphael, Augusto e Cleópatra, 1760.

Batoni, Pompeo, A Morte de Marco António, 1763.

Hamilton, Gavin, O Juramento de Brutus, 1763-1764.

Hamilton, Gavin, Cleópatra, 1767-1769.

Kauffmann, Angelika, Cleópatra decorando o túmulo de Marco António, 1769-1770. 
Beaufort, Jacques-Antoine, O Juramento de Brutus, 1771.

David, Jacques-Louis, Antioco e Estratonice, 1774.

Tischbein, Johann Heinrich (o Antigo), António e Cleópatra, 1774.

Regnault, Jean-Baptiste, Diógenes visitado por Alexandre, 1776.

Hallé, Noël, Cornélia mãe dos Gracos, 1779.

Lacour, Pierre, Cleópatra lamentando-se no túmulo de Marco António, 1781.

Ménageot, François Guillaume, Cleópatra no túmulo de Marco António, 1785.

Gauffier, Louis, Entrevista de Augusto e Cleópatra depois da batalha de Áccio, 1788.

David, Jacques -Louis, Os lictores devolvendo a Brutus os corpos de seus filhos, 1789.

Duvivier, Johannes Bernardus, Cleópatra capturada pelos soldados romanos após a morte de Marco António, 1789.

Cades, Giuseppe, Alexandre, o Grande recusa beber água, 1792

Topino-Lebrun, Jean-Baptiste, A morte de Gaio Graco, 1792.

LeTHIÈRE, Guillaume, A morte de Catão em Útica, 1795.

Regnault, Jean-Baptiste, A Morte de Cleópatra, c. $1796-1797$ 
Bouchet, Louis-André-Gabriel, A morte de Catão de Útica, 1797.

Bouillon, Pierre, A morte de Catão de Útica, 1797.

GuÉrin, Pierre-Narcisse, A morte de Catão de Útica, 1797.

David, Jacques-Louis, A Intervenção das Mulheres Sabinas, 1799.

\section{SÉculo XIX}

Guérin, Pierre-Narcisse, O Casamento de Alexandre, $o$ Grande e Roxana, séc. XIX.

Camuccini, Vincenzo, Os Idos de Março / A morte de César, c. 1800.

Camuccini, Vincenzo, O Triunfo de César, c. 1800.

Camuccini, Vincenzo, Rómulo e Remo descobertos, c. 1800.

Odevaëre, Joseph-Denis, $A$ morte de Fócion, 1804 (Catão).

Boisselier, Félix, A Morte de Demóstenes, 1805.

Heim, François-Joseph, Teseu vencedor do Minotauro, 1807.

Pujol, Alexandre Denis Abel de, A clemência de César, 1808.

Pujol, Alexandre Denis Abel de, Licurgo apresenta aos Lacedemónios o herdeiro do trono, 1811.

Boisfremont, Charles-Pompée le Boulanger de, $A$ 
Morte de Cleópatra, 1824-1828.

Dupré, François-Xavier, Coriolano na casa de Tulo, rei dos Volscos, 1827.

Bracassat, Jacques-Raymond, Coriolano e sua mãe, 1831.

Flandrin, Hippolyte, Teseu reconhecido por seu pai, 1832.

Delacroix, Eugène, Cleópatra e o Camponês, 1838.

Brisset, Pierre-Nicolas, A Partida de Gaio Graco, 1840.

Ingres, Jean-Auguste, Antíoco e Estratonice, 1840.

Ulmann, Benjamin, Coriolano em casa de Tulo, rei dos Volscos, 1859.

Dejusssieu, Henri Blaise François, Cleópatra ou Cleópatra e a escrava, 1863.

Hillemacher, Eugéne Ernest, António moribundo levado até Cleópatra, 1863.

Gérôme, Jean-Léon, A Morte de César, 1867.

Nouy, Jean Lecomte du, Demóstenes praticando a oratória, 1870.

Giannetti, Raffaele, $O$ último senado de Júlio César, 1867.

Böcklin, Arnold, A Morte de Cleópatra, 1872.

Rixens, Jean André, A Morte de Cleópatra, 1874.

Makart, Hans, A Morte de Cleópatra, 1875.

BöCKLIn, Arnold, A Morte de Cleópatra, 1878. 
Alma-Tadema, Sir Lawrence, $O$ reencontro de António e Cleópatra, 41 a.C., 1883.

Moreau, Gustave, O Triunfo de Alexandre, o Grande, c. 1885 .

Cabanel, Alexandre, Cleópatra ensaiando os venenos nos condenados à morte, 1887.

Collier, John, A Morte de Cleópatra, 1890.

Royer, Lionel-Nöel, Vercingétorix rende-se a César, 1899. 


\section{AneXo III}

\section{LISTAGEM DAS OBRAS POR PERSONAGENS MAIS REPRESENTADAS}

\section{Rómulo e Remo}

Blanchard, Marte e a Vestal Virginia, c. 1630.

Rubens, Pieter Paul, Marte e Reia Sílvia, 1616-1617.

Camuccini, Vincenzo, Rómulo e Remo descobertos, c. 1800 .

Pauwel, Pieter, Rómulo e Remo, 1615-1616.

Cortona, Pietro de, Rómulo e Remo acolhidos por Fáustulo, c. 1643.

Gauffier, Louis, Rómulo em Remo em casa de Fáustulo e Aca Larência, séc. XVIII.

Ricci, Sebastiano, Infância de Rómulo e Remo ou Rómulo em Remo em casa de Fáustulo e Aca Larencia, c. 1708 .

Rubens, Pieter Paul, Rómulo e Remo em crianças, 1614.

Cortona, Pietro de, O Rapto das Mulheres Sabinas, 1627-1629.

Poussin, Nicolas, O Rapto das Mulheres Sabinas, 1634-1635.

Poussin, Nicolas, O Rapto das Mulheres Sabinas, 1637-1638.

Rubens, Pieter Paul, $O$ Rapto das Sabinas, 1635-1637. 
Schönfeld, Johann Heinrich, O Rapto das Mulheres Sabinas, 16301650.

Sodoma II, O Rapto das Mulheres Sabinas, 1506-1507.

David, Jacques-Louis, A Intervenção das Mulheres Sabinas, 1799.

Guercino, Hersília separando Rómulo de Tácio, 1645.

\section{Coriolano}

Dupré, François-Xavier, Coriolano na casa de Tulo, rei dos Volscos, 1827.

Ulmann, Benjamin, Coriolano em casa de Tulo, rei dos Volscos, 1859.

Аввінті, Filippo, Coriolano persuadido pela sua familia a poupar Roma, 1661.

Biscaino, Bartolomeo, Coriolano recebendo as matronas romanas, c. 1725.

Brascassat, Jacques-Raymond, Coriolano e sua mäe, 1831.

Eecкоuт, Gerbrand von der, Volúmnia perante Coriolano, séc. XVII.

Poussin, Nicolas, Coriolano perante a súplica de sua mãe, 1650.

Signorelli, Luca, Coriolano persuadido pela sua familia a poupar Roma, c. 1509.

Tiepolo, Giovanni Battista, Coriolano, c. 1730. 
Verona, Michele de, Coriolano persuadido pela sua familia a poupar Roma, 1495-1510.

\section{JÚlIO CÉSAR}

Camuccini, Vincenzo, O Triunfo de César, c. 1800.

Mantegna, Andrea, O Triunfo de César, dp. 1486.

Sarto, Andrea del, O Triunfo de César, c. 1520.

Uccello, Paolo, O Triunfo de César, séc. XV.

Fouquet, Jean, A fuga de Pompeio depois da batalha de Farsália, séc. XV.

FouQuet, Jean, César atravessando o Rubicão, séc. XV.

Feselen, Melchior, Alésia cercada por Júlio César, séc. XVI.

Royer, Lionel-Nöel, Vercingétorix rende-se a César, 1899.

Pujol, Alexandre Denis Abel de, A clemência de César, 1808.

Giannetti, Raffaele, O último senado de Júlio César, 1867.

Camuccini, Vincenzo, Os Idos de Março / A morte de César, c. 1800

Gérôme, Jean-Léon, A Morte de César, 1867.

\section{Catáo}

OdevaËre, Joseph-Denis, A morte de Fócion, 1804 (Catão). 
Stomer, Matthias, Catão tirando a venda, séc. XVII. Amalteo, Pomponio, A morte de Catão, c. 1580. Assereto, Gioacchino, O suícidio de Catão, c. 1639. Beccafumi, Domenico, A morte de Catão, c. 1519. Bouchet, Louis-André-Gabriel, A morte de Catão de Útica, 1797.

Bouillon, Pierre, A morte de Catão de Útica, 1797.

Cignaroli, Giambettino, A Morte de Catão, séc. XVII?

GuÉRIn, Pierre-Narcisse, A morte de Catão de Útica, 1797.

Langetti, Giovanni Battista, Catão, 1660-1680.

Lethière, Guillaume, A morte de Catão em Útica, 1795.

Perugino, Pietro, Catão, 1497-1500.

Stomer, Matthias, A Morte de Catão, séc. XVII

\section{AleXandre}

Romano, Giulio, Imperador Alexandre, 1532.

Moreau, Gustave, O Triunfo de Alexandre, o Grande, c. 1885 .

Robert, Hubert, Capriccio de Templo Romano. Entrada Triunfal de Alexandre, o Grande, 1755-1760.

Altdorfer, Albrecht, A Batalha de Alexandre, 1529.

Brueghel, Jan (o velho), A Batalha de Isso, 1602. 
Anónimo (Miniaturista flamengo), História de Alexandre, o Grande, 14501490.

Conca, Sebastiano, Alexandre, o Grande no Templo de Jerusalém, 17351737.

Strozzi, Bernardo, Alexandre o Grande restaurando o trono usurpado a Abdolomino, séc. XVI.

Piazzetta, Giovanni Battista, A Morte de Dario, c. 1746 .

Diziani, Gaspare, A familia de Dario perante Alexandre, o Grande, séc. XVIII.

Le Brun, Charles, A familia de Dario perante Alexandre, c. 1660.

Sodoma II, As mulheres da familia de Dario perante Alexandre, o Grande, c. 1517.

Tiepolo, Giovanni Battista, A familia de Dario perante Alexandre, O Grande, 1743.

Tiepolo, Giovanni Battista, Alexandre, o Grande com a mulher de Dario, 1750-1753.

Veronese, Paolo, A família de Dario perante Alexandre, 1565-1570.

Le Brun, Charles, Entrada de Alexandre em Babilónia, c. 1664 .

Tiepolo, Giovanni Battista, Alexandre, o Grande e Campaspe no estúdio de Apeles, 1725-1726.

Tiepolo, Giovanni Battista, Alexandre, o Grande e Campaspe no estúdio de Apeles, 1740. 
Vleughels, Nicolas, Apeles pintando uma paisagem, 1756.

Domenichino, Timocleia cativa trazida perante Alexandre, c. 1615.

Crayer, Gaspar de, Alexandre e Diógenes, séc. XVII.

Langetti, Giovanni Battista, Diógenes e Alexandre, c. 1650 .

Regnault, Jean-Baptiste, Diógenes visitado por Alexandre, 1776.

Le Brun, Charles, Alexandre e Poro, 1665.

GuÉRIn, Pierre-Narcisse, O Casamento de Alexandre, o Grande e Roxana, séc. XIX.

Sodoma II, O Casamento de Alexandre e Roxana, c. 1517.

Rotari, Pietro Antonio, Alexandre, o Grande $e$ Roxana perante o túmulo de Aquiles, 1756.

Schönfeld, Johann Heinrich, Alexandre, o Grande perante o túmulo de Aquiles, c. 1630.

Cades, Giuseppe, Alexandre, o Grande recusa beber água, 1792

\section{Cleópatra}

Tintoretto, A libertação de Arsinoe, c. 1556.

Lairesse, Gérard de, O desembarque de Cleópatra em Tarso ou Páris e Helena desembarcando em Tróia, 1685-1690. 
Alma-Tadema, Sir Lawrence, O reencontro de António e Cleópatra, 41 a.C., 1883.

Bourdon, Sébastien, $O$ reencontro de António e Cleópatra, c. 1645.

Gellée, Claude (dito Le Lorrain), O desembarque de Cleópatra em Tarso ou Páris e Helena desembarcando em Tróia, 1642.

Natoire, Charles-Joseph, O reencontro de Marco António e Cleópatra em Tarso, 1741-1755.

Natoire, Charles-Joseph, A chegada de Cleópatra a Tarso, 1756

Tiepolo, Giovanni Battista, O reencontro de António e Cleópatra, 17461747.

Tischbein, Johann Heinrich (o Antigo), António e Cleópatra, 1774.

LaIresse, Gérard de, O banquete de Cleópatra, c. 1675.

Luçon, Mestre de, Banquete de Cleópatra, iluminura do manuscrito de Boccaccio (ce), Des casibus virorum ilustrium, Des cas des nobles hommes et femmes, tradução francesa de Laurent de Premiierfait, vol. II, fol. 26, c. 1410.

Natoire, Charles-Joseph, O Banquete de Cleópatra e Marco António, 1754.

Steen, Jan, O Banquete de António e Cleópatra, 1668-1669.

Tiepolo, Giovanni Battista, O Banquete de Cleópatra, 1743-1744.

Tiepolo, Giovanni Battista, O Banquete de Cleópatra, 
$1746-1747$.

Cabanel, Alexandre, Cleópatra ensaiando os venenos nos condenados à morte, 1887.

Dejussieu, Henri Blaise François, Cleóatra ou Cleópatra e a escrava, 1863.

Delacroix, Eugène, Cleópatra e o Camponês, 1838.

Hillemacher, Eugéne Ernest, António moribundo levado até Cleópatra, 1863.

Tischbein, Johann Heinrich (o Antigo), António moribundo junto de Cleópatra, 1767-1769.

Anónimo, A Morte de António e Cleópatra, iluminura do manuscrito de Boccaccio (ce), Des casibus virorum ilustrium, Des cas des nobles hommes et femmes, tradução francesa de Laurent de Premiierfait, vol. II, fol. 190v, 1460-1470.

Luçon, Mestre de, A Morte de António e Cleópatra, iluminura do manuscrito de Boccacio (ce), Des casibus virorum ilustrium, Des cas des nobles hommes et femmes, tradução francesa de Laurent de Premiierfait, vol. II, fol. 66, c. 1410.

Batoni, Pompeo, A Morte de Marco António, 1763.

Kauffmann, Angelika, Cleópatra decorando o túmulo de Marco António, 1769-1770.

Ménageot, François Guillaume, Cleópatra no túmulo de Marco António, 1785.

Lacour, Pierre, Cleópatra lamentando-se no túmulo de Marco António, 1781. 
Duvivier, Johannes Bernardus, Cleópatra capturada pelos soldados romanos após a morte de Marco António, 1789.

Anónimo (discip. Nicolas Poussin), Cleópatra e Octávio, séc. XVII.

Barbieri, Giovanni Francesco (dito Le Guerchin), Cleópatra perante Octávio Augusto, c. 1640.

Gauffier, Louis, Entrevista de Augusto e Cleópatra depois da batalha de Accio, 1788.

Gravelot, Hubert François, Augusto e Cleópatra, séc. XVIII

Mengs, Anton Raphael, Augusto e Cleópatra, 1759.

Mengs, Anton Raphael, Augusto e Cleópatra, 1760.

Anónimo (pintor activo em Veneza e Emília no final do século XVI), O Suicídio de Cleópatra, c. 1580 .

Böcklin, Arnold, A Morte de Cleópatra, 1872.

Böcklin, Arnold, A Morte de Cleópatra, 1878.

Boisfremont, Charles-Pompée le Boulanger de, $A$ Morte de Cleópatra, 1824-1828.

Brusasorci, Domenico, O Suicídio de Cleópatra, 1550-1555.

Cagnacci, Guido, Cleópatra, c. 1659.

Cagnacci, Guido, A Morte de Cleópatra, c. 1659/ 1661-1662.

Collier, John, A Morte de Cleópatra, 1890. 
Cozza, Francesco, Cleópatra oferecendo-se à morte, 1675.

Ferrari, Luca, A Morte de Cleópatra, c. 1650.

Fontana, Lavinia, Cleópatra, c. 1585.

Gentileschi, Artemisa, Cleópatra, c. 1620.

Ghirlandaio, Michele di Ridolfo del, O Suicídio de Cleópatra, c. 1560.

Hamilton, Gavin, Cleópatra, 1767-1769.

Hoet, Gérard, A Morte de Cleópatra, séc. XVIII.

JaCopo, Giovanni Battista (dito Il Rosso Fiorentino), A Morte de Cleópatra, 1524-1527.

Jordaens, Jacob, A Morte de Cleópatra, 1653.

LaIresse, Gérard de, A Morte de Cleópatra, 1675-1680.

Liss, Johann, A Morte de Cleópatra, 1622-1624.

Makart, Hans, A Morte de Cleópatra, 1875.

Mazzoni, Sebastiano, A Morte de Cleópatra, 1660.

Mignard, Pierre, A Morte de Cleópatra, séc. XVII.

Negroni, Pietro, O Sucídio de Cleópatra, c. 1545.

Pulgo, Domenico, A Morte de Cleópatra, séc. XV-XVI.

Regnault, Jean-Baptiste, A Morte de Cleópatra, c. 1796-1797.

Reni, Guido, Cleópatra e a áspide, c. 1630.

Reni, Guido, A Morte de Cleópatra, 1625-1626.

Reni, Guido, O Suicídio de Cleópatra, 1639-1640. 
Rivalz, Antoine, A Morte de Cleópatra, séc. XVIII.

Rivalz, Antoine, Cleópatra, séc. XVIII.

Rixens, Jean André, A Morte de Cleópatra, 1874.

Vignon, Claude, A Morte de Cleópatra, séc. XVII.

Tischbein, Johann Heinrich (o Antigo), Augusto à cabeceira de Cleópatra moribunda, 1769. 